
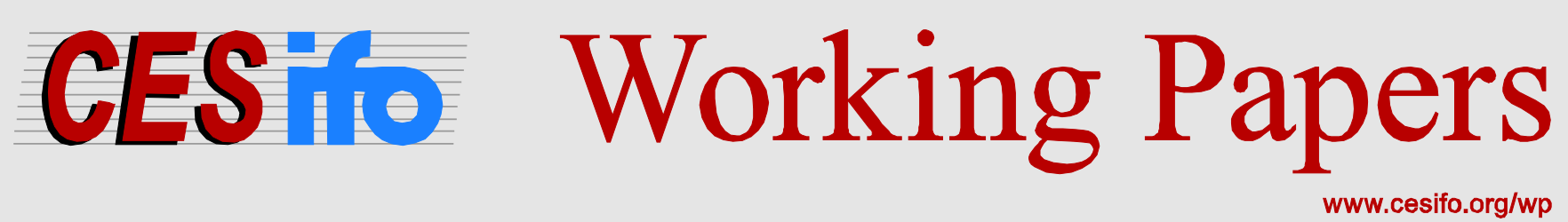

\title{
The Impact of Foreclosure on Housing Prices
}

\author{
Ralph Siebert
}

\author{
CESIFO WORKING PAPER NO. 5196 \\ CATEGORY 11: INDUSTRIAL ORGANISATION \\ JANUARY 2015
}

ISSN 2364-1428

An electronic version of the paper may be downloaded

- from the SSRN website:

- from the RePEc website:

- from the CESifo website:

www.SSRN.com

Www.RePEc.org

www.CESifo-group.org/wp

\section{CESifo}




\title{
The Impact of Foreclosure on Housing Prices
}

\begin{abstract}
The aim of the study is to explain if the foreclosure effect on prices is explained by a lower quality of foreclosed houses, which is a crucial aspect in the intelligibility of foreclosures. Based on a novel and comprehensive dataset, we estimate the impact of foreclosure on home prices in Florida and Indiana from 2000 to 2008. We employ a model of housing demand, which enables us to flexibly estimate (unobserved) quality as a house-specific fixed effect. We find that house-specific quality explains the vast majority of the foreclosure effects on house prices. Our results also show that foreclosed homes in Florida and Indiana lost a considerable amount of value. For example, foreclosed homes in Fort Lauderdale (Florida) lost, on average, \$42; 110 (12 percent) of the average house price in Florida), while foreclosed houses in Lafayette (Indiana) lost \$23; 798, which corresponds to 16:1 percent of the average house price in Indiana. The estimation results show a significant degree of heterogeneity. In much of Florida, foreclosed houses lost most value at the upper part of the house size and income distributions. In contrast, foreclosed houses in Indiana lost most value at the lower part of those distributions. Finally, we show that non-foreclosed houses agonized losses (from 0:8 percent to 4:7 percent) due to other houses in the neighborhood being foreclosed.
\end{abstract}

JEL-Code: C100, L100, L600, O300.

Keywords: demand estimation, foreclosure, housing market, nonparametrics, hedonic pricing equation.

\author{
Ralph Siebert \\ Purdue University \\ Department of Economics \\ Krannert School of Management \\ 403 West State Street \\ USA - 47907-2056 West Lafayette IN \\ rsiebert@purdue.edu
}

November 2014 


\section{Introduction}

The financial crisis of 2007 to 2012 caused a great recession at a global level. It severely affected the stock and real estate markets, caused large unemployment rates and provoked extraordinary losses in investments and savings. ${ }^{1}$ From 2007 to 2009, eight million jobs were lost in the United States, and in 2009, more than four million households lost their homes due to foreclosures; every eight seconds, a house was foreclosed. ${ }^{2}$ The burst of the real estate bubble and the increased foreclosure rates in 2006 destroyed wealth, investments and potential savings. Several financial institutions and mortgage lenders lost considerable wealth and faced bankruptcies. Foreclosure destroyed wealth, since banks forfeited losses from illiquid mortgages and homeowners suffered losses to their home values. $^{3}$ Moreover, other homeowners feared losses on their own homes due to neighboring houses getting foreclosed, also referred to as neighborhood, or congestion, or spillover effects (see also Campbell, Giglio, and Pathak (2011) and Harding, Rosenblatt and Yao (2008)). Homeowners across the entire nation became concerned that their own home values would depreciate, partly due to neighborhood effects.

The aim of this study is to provide insights into the impact of foreclosures on home values. We concentrate on providing answers to the following questions: Do foreclosed homes experience a plunge in their values? If so, how much do foreclosed homes forfeit? To what extent do foreclosed homes lose value because their house quality degraded? Is there heterogeneity in the impact of foreclosure with regard to geographic areas, income and house size distributions? Finally, do foreclosed houses lower the value of non-foreclosed neighboring homes?

Houses are fragile assets that need maintenance, and the deficiency of savings would cause poor maintenance and defer necessary renovations and repairs, diminishing home

\footnotetext{
${ }^{1}$ For further information on the impact of the financial crisis on residential investments and consumer demand, see Mian, Sufi and Trebbi (2014).

${ }^{2} \mathrm{~A}$ foreclosure occurs when a homeowner has defaulted on mortgage payments, leading to the property being sold. More detailed information on the foreclosure process is provided in the next section.

${ }^{3}$ Mian and Sufi (2014) provide an excellent overview on the relationship between the financial crisis and the housing market.
} 
quality. Moreover, given the fact that foreclosed houses frequently stay vacant for an extended period of time, they require more maintenance. Figures 1 to 3 show examples of foreclosed houses with low quality. Accounting for quality is crucial in the context of foreclosure, as those houses are frequently in poor condition. Hence, house quality is an important variable in the context of foreclosure because lower quality of foreclosed houses might be a significant explanatory component in explaining lower house prices of foreclosed homes. Foreclosed houses may also reduce the visual appeal and social cohesion of the neighborhood and encourage crime (see also Campbell, Giglio and Pathak (2011), Apgar, Duda and Gorey (2005) and Immergluck and Smith (2005, 2006)), such that foreclosure might have a price reducing impact on home value in the neighborhood. ${ }^{4}$ Hence, the impact of foreclosure on house prices is not constrained to the own home, but might also affect other houses in the neighborhoods.

Our goal is to explain if the foreclosure effect on prices is explained by the fact that foreclosed houses are characterized by lower quality which reduces prices. However, analyzing the impact of foreclosure on housing prices is a challenging problem since house quality is only rarely, if at all, observed by the econometrician, even though it is observed by the home buyers. ${ }^{5}$ We estimate an empirical model of housing demand which allows us to estimate the foreclosure effect on price. We are especially interested in evaluating to what extent (unobserved) house-specific quality explains price discounts of foreclosed homes.

The model is flexibly estimated using a nonparametric estimation technique as suggested by Bajari and Kahn (2005). ${ }^{6}$ The estimation method imposes few restrictive distributional assumptions, which eventually allows us to flexibly estimate house-specific

\footnotetext{
${ }^{4}$ There are various reasons why neighborhood effects might arise. Another common reason is that other foreclosed homes in the neighborhood will become reference cases used when a home appraisal is done, likely reducing the appraised value of the listed home. See also Cutler and Glaeser $(1997,1999)$ for further information on neighborhood effects in the housing market.

${ }^{5}$ One might think that the appraised value of houses might be a good proxy for quality. However, appraised home values have to be interpreted cautiously, as those values are based on purchase prices of foreclosed houses as reference cases, or neighborhoods that were affected by foreclosures.

${ }^{6}$ See also the study by Bajari and Benkard (2005) that suggests a similar estimation procedure.
} 
quality as a house-specific fixed effect which is retrieved from the residual. ${ }^{7}$

Our study most closely relates to an excellent study by Campbell, Giglio and Pathak (2011) which examines the effect of forced sales (deaths, bankruptcies and foreclosures) on house prices in Massachusetts from 1987 to 2009. Their estimation results return an average price discount of 27 percent for foreclosures. The authors find that foreclosure discounts are larger for low-priced properties in low-income neighborhoods. They interpret this finding, and surmise that foreclosed homes might have been damaged or vandalized before they were sold. This explanation has been implicitly derived from their findings, i.e., discounts are larger for low-priced properties in low-income neighborhoods, rather than explicitly tested. Hence, Campbell, Giglio and Pathak (2011) inferred from their results that foreclosed houses at the lower end of house value distribution might have suffered from lower quality and vandalism.

Beyond evaluating a potential foreclosure impact at low-priced properties or low income neighborhoods, our study provides further insight about a potential impact of foreclosure on house prices at the intermediate or upper end of the house value or income distributions. Our model explicitly accounts for house-specific quality which enables us to account for the heterogeneous impact of foreclosure on housing prices along the entire house value distribution. Hence, we provide new insights regarding the heterogeneity of the foreclosure effect on prices. We are not aware of any study that evaluates the heterogeneous impact of foreclosure on house prices which accounts for (unobserved) house quality.

A quality downgrade of foreclosed houses is not the only potential reason why foreclosed houses would lose value. Another reason is that lenders or banks realized missing income streams as borrowers defaulted on payments (see Campbell, Giglio and Pathak (2011)). The banks do not achieve utility or interest from repossessing and keeping foreclosed houses. Rather, they experience losses on the potential interest on capital they could

\footnotetext{
${ }^{7}$ On a related note, earlier studies have emphasized the importance of explicitly accounting for unobserved product (quality) characteristics, as they are not truly random components. Not accounting for quality in our case might bias the estimated price elasticity toward zero (see, e.g., Bajari and Benkard (2005), Berry (1994), Berry, Levinsohn and Pakes (1995), Nevo (2001), Petrin (2002), Ackerberg and Rysman (2002), Goolsbee and Petrin (2004), and Bayer, McMillan and Rueben (2004)).
} 
have earned if they sold the house. Hence, banks have a high incentive to sell the house quickly to minimize their losses from foregone investment opportunities.

Several excellent empirical articles focus on evaluating the impact of foreclosure. Campbell, Giglio, and Pathak (2011) estimate the effect of forced sales (deaths, bankruptcies and foreclosures) on house prices in Massachusetts from 1987 to 2009. Mian, Sufi and Trebbi (2014) provide an overall assessment of foreclosures on real economic activity, such as residential investment and consumer demand. Their analysis evaluates the aggregate impact of foreclosure across the entire U.S. using observations at the state and city levels. They find that states without judicial requirements for foreclosures are twice as likely to foreclose on delinquent homeowners than are states enforced by judicial law. They show that foreclosures lead to a large decline in house prices, residential investment and consumer demand. Further seminal studies that focus on foreclosures and house prices are Calomiris, Longhofer and Miles (2008), Foote, Gerardi and Willen (2008) and Hartley (2010).

Based on a novel and comprehensive dataset that includes all registered residential housing transactions in the real estate market in Florida and Indiana from 2000 to 2008, we estimate the impact of foreclosure on home prices. ${ }^{8}$ Based on summary statistics and hedonic regression analyses, we find that foreclosures are realized across the entire house size and income distribution, as well as across other sociodemographic variables. ${ }^{9}$ We proceed with estimating a housing demand model, as suggested by Bajari and Kahn (2005), which allows us to flexibly estimate house-specific quality component. ${ }^{10}$ We estimate a nonparametric house price function using local polynomial methods, of which the error term characterizes a vertical product characteristic. ${ }^{11}$

\footnotetext{
${ }^{8}$ The registration refers to the Multiple Listing Service, which is a database used by realtors.

${ }^{9}$ We will address the issue to what extent the relationship between foreclosure and prices is determined by a potential omitted variable biases and selectivity (as discussed by Campbell, Giglio, and Pathak (2011)) below.

${ }^{10}$ The method is closely related to Epple and Sieg (1999) and Bayer et al. (2004).

${ }^{11} \mathrm{~A}$ further advantage of the estimator is that it accounts for heterogeneity in preferences for housing attributes. Epple and Sieg (1999), Sieg, Smith, Banzhaf and Walsh (2002) and Bayer, McMillan and Rueben (2004) introduced models that account for heterogeneity in preferences.
} 
In our study, we mainly concentrate on four different markets: Fort Lauderdale (FL), Hollywood (FL), Miami (FL) and Lafayette (IN). Our study provides interesting and insightful results related to the impact of foreclosure on home prices. The estimation results on foreclosure also show a significant degree of heterogeneity across house size distributions, income distribution of neighborhoods and geographic regions. With regard to geographic differences, we find that foreclosed homes in Fort Lauderdale (FL) lost $\$ 42,110$ in value, which corresponds to 12 percent of the average price for a house in Florida. Foreclosed houses in Lafayette (IN) lost on average $\$ 23,798$, which corresponds to 16.1 percent of the average price for a house in Indiana.

With regard to house size and income differences across regions, we find that foreclosed houses in Fort Lauderdale experienced a loss of $\$ 17,371$ (6.2 percent) in the lower market segment of the house size distribution, while houses in the upper segment lost $\$ 211,750$ (32.1 percent). Moreover, foreclosed homes in Fort Lauderdale lost 10.2 percent of the home value in low-income areas and 23.4 percent in high-income areas. The losses at the upper segment are immense and support anecdotal evidence that speculative investments in the real estate market and the resulting housing bubble burst caused large losses due to foreclosures at the upper market segment. In contrast, foreclosed houses in Lafayette lost most of the value at the lower market segment of the house size distribution, $\$ 22,469$ (19.34 percent) and experienced fewer losses on the upper market segment, $\$ 25,215$ (13.23\%). Moreover, foreclosed houses in Lafayette and Hollywood lost the most value (in absolute and relative terms) in low-income neighborhoods.

We find that the vast majority (92 percent) of the home losses of foreclosed homes are explained by lower quality. Only a minor fraction relates to the fact that foreclosed houses are sold sooner on the market by lenders who repossessed the foreclosed homes to avoid foregone investment opportunities.

We also provide interesting insights with regard to neighborhood effects, i.e., whether non-foreclosed houses experienced losses as a response to other houses being foreclosed in the neighborhood. The results show that non-foreclosed homes lost from 0.8 to 4.7 
percent, depending on the geographic location. Consequently, the results provide evidence that the foreclosure problem is not only constrained to foreclosed homes, but becomes a nationwide concern as it spreads out toward neighboring homes.

Overall, our estimation results return reasonable estimates of buyers' willingness to pay for housing attributes. The implicit prices for housing characteristics are significantly higher in Florida than in Indiana. For example, the implicit price for an additional square foot in Fort Lauderdale is $\$ 300.82$, while it is only $\$ 73.71$ in Lafayette. This result explains the fact that houses in Florida are on average three times more expensive than in Indiana. Neighborhood demographics critically depend on the geographic market. For example, in Fort Lauderdale, the willingness to pay for houses in Hispanic neighborhoods is higher compared to black or white neighborhoods. In contrast, in Hollywood and Indiana, the implicit price is higher for white neighborhoods.

This article is organized as follows: Section 2 provides information about the foreclosure process. Section 3 introduces the data sources and presents summary statistics. Section 4 introduces the housing model and presents the results. Section 5 concludes.

\section{The Foreclosure Process}

Beginning in 2000, speculation in the real estate market considerably raised prices and played a major role in establishing the bubble in the real estate market. Speculators, who anticipated a profit from a sale in a short period of time, increased their investment activities. Housing prices peaked in early 2006 and started to decline in 2006 and 2007. After the speculation bubble eventually burst in 2007, the real estate market collapsed, causing price declines of 30 to 50 percent (see, e.g., the S\&P/Case-Shiller Home Price Indices). The real estate market suffered extraordinary losses especially at the upper end of the home value distribution. Housing bubbles were more developed in areas such as Florida and California, where speculations were established and homeowners purchased second homes for vacationing or retirement. Private investors who were struck by negative 
income shocks defaulted on their mortgage payments and were forced to sell their homes at low prices. In fact, many foreclosures in Florida and California were caused by speculative investments, and the largest number of foreclosure filings were registered in Florida and California, as well as in large metropolitan areas. ${ }^{12}$ In the U.S. Midwest, housing assets did not appreciate as much, and investing in assets is not the primary reason consumers purchase homes (see the Annual National Association of Realtors). Housing prices also remained more stable after the burst in the housing bubble. Hence, foreclosures are likely to have different impacts on home values across geographic regions, e.g., different cities.

The foreclosure problem became a nationwide concern and received considerable attention in the media. There is a wide consensus that the intensified collapse of the housing market, which accounts for a major fraction of wealth, is the primary cause of the 2007 to 2009 economic recession. ${ }^{13}$ In 2008, before the presidential elections, many politicians, economists and policy makers claimed that the recovery of the financial crisis and the economy heavily depended on the surge of the housing market. Government interventions were suggested, but Democrats and Republicans had different perspectives and raised different viewpoints for tailoring financial support to homeowners. There were differences of opinion on who was most severely affected by foreclosure and, therefore, should be eligible for financial support. Many politicians wanted to support low-income homeowners, since more of them were facing foreclosure. Others were in favor of supporting high-income homeowners, as expensive houses are likely to suffer from a higher value loss and a higher loss is considered more harmful to the economy.

During and after the recession, policy makers and politicians applied several governmental instruments to recover the economy, to stimulate investments and to address the mortgage crisis. The United States government allocated more than $\$ 900$ billion to special loans and rescues related to the U.S. housing market bubble, interest rates were reduced

\footnotetext{
${ }^{12}$ Calomiris, Longhofer and Miles (2008) mention "...through 2009 only 12 states realized price declines of 6 percent or more, led by Nevada, Florida, California, and Arizona."

${ }^{13}$ The 2013 Survey of Consumer Finances estimated the value of primary residences in the U.S. to be more than $\$ 10$ trillion.
} 
and companies were bailed out. In 2008, the "Housing and Economic Recovery Act" was signed, which authorized the Federal Housing Administration to invest up to $\$ 300$ billion in new 30-year fixed rate mortgages. The purpose of the Act was to restore confidence in Fannie Mae and Freddie Mac (both of which are government-sponsored enterprises) and to inject capital into the two large U.S. suppliers of mortgage funding. ${ }^{14}$ At the end of 2009, the Treasury Department announced that it would be providing Fannie Mae and Freddie Mac unlimited financial support for the next three years.

Many policy makers blamed the foreclosure problem on financial institutions who applied less stringent norms in assessing credit worthiness of the borrowers. Moreover, more intense competition in the financial sector drastically increased the supply of mortgages. Consequently, banks issued (subprime) mortgages at higher risk and many illiquid mortgages were issued to homeowners who were originally not eligible and could not afford to purchase homes. Homeowners soon defaulted on their payments and faced foreclosure.

Even though foreclosure is frequently associated with default on mortgage payments by homeowners at the lower segment of the house and income distributions, home foreclosures were realized across the entire society. Most people who sign a mortgage do not intend to walk away from it. Unforeseen incidences, such as illiquid mortgages, job losses, bankruptcy, medical bills, divorce, eroding property values or wealth loss on pensions, and negative income shocks can lead to foreclosure. Even the best-intended borrowers and wealthy owners were struck by unforeseen events leading to foreclosure. Hence, households across the entire house value and income distributions were potentially affected by foreclosure.

A foreclosure is considered a necessary instrument to protect the investor's interest in the property and to salvage the borrower's equity. Foreclosures were a potential threat across the entire population, independent of wealth or income. One prominent example of foreclosure at the upper end of the wealth distribution is the case of the former boxing

\footnotetext{
${ }^{14}$ Fannie Mae and Freddie Mac buy mortgage loans from lenders, thereby ensuring that mortgage money is available at all times in all locations around the country.
} 
champion Evander Holyfield, who moved out of his palatial Fayette County (Georgia) estate after it was sold as a foreclosure in 2012. The home has 11 bedrooms, 17 bathrooms, a bowling alley, a movie theater, huge exercise rooms and a dining room with a table large enough to accommodate 32 upholstered chairs (see Figure 4).

Depending on the state where the house is located, the servicer's representative may record a formal notice of foreclosure at the local courthouse, publish details of the debt in the local newspaper, attend hearings on the case and make appropriate court filings. It is common to distinguish between judicial and nonjudicial foreclosure processes. In states with judicial foreclosures, lenders have to retake property titles via the court system. ${ }^{15}$ The timeline for judicial foreclosures can be summarized as follows: If a mortgage payment becomes 45 to 60 days overdue, the servicer sends a letter to the borrower pointing out that terms of the mortgage have been violated. If payments are 90 days overdue, the servicer will initiate a formal foreclosure proceeding. After three to six months of missed payments, the lender orders a trustee to record a "Notice of Default" (NOD). The borrower is notified of the foreclosure case. Until this point, the case is still categorized as a preforeclosure. After six to nine months, if the loan has not been paid, a foreclosure sale date is established. The homeowner will receive a "Notice of Sale," which will also be posted on the property. An order signed by a judge will be published to sell the property at public auction, also referred to as "Notice of Trustee's Sale" (NTS). The house is posted for sale at an auction. The bank sets an opening bid at an amount that covers the mortgage, plus the debt, interest, penalties and processing costs that have accrued prior to the sale. The property is auctioned to the highest bidder, who must pay the highest submitted bid price in cash. If nobody enters a bid in excess of that amount, the bank obtains the property by default, also referred to as "Real Estate Owned" (REO), which applies to approximately 90 percent of the cases. It is important to note that only 10-15 percent

\footnotetext{
${ }^{15}$ Twenty-two states follow judicial procedures as the primary way to foreclose. The states include: Connecticut, Delaware, Florida, Hawaii, Illinois, Indiana, Iowa, Kansas, Kentucky, Louisiana, Maine, New Jersey, New Mexico, New York, North Dakota, Ohio, Oklahoma, Pennsylvania, South Carolina, South Dakota, Vermont and Wisconsin.
} 
of the foreclosed houses are sold in auctions, and approximately 90 percent of the houses are eventually offered on the market by real estate agents. The servicer then usually sells the property on the market using a real estate company.

In nonjudicial foreclosures, no court intervention takes place. In case a default is realized, the borrower receives a default letter followed by a "Notice of Sale," which is posted in public places. After the legally required notice period has expired, the house is repossessed by the bank.

\section{The Data Sources and Summary Statistics}

Our study focuses on residential housing from 2000 to 2008. We concentrate on Florida and Indiana, since both states apply the judicial system in processing foreclosures. Moreover, the housing markets in those states are characterized by different features which will have different impacts on foreclosed home prices. In Florida, speculators and investors have undertaken large real estate investments. Florida was also dramatically affected by the housing bubble burst that had a strong impact on the real estate market. In Indiana, speculative investments were not common and the housing bubble burst did not have a significant impact, so housing prices remained rather stable. Moreover, the states are characterized by sociodemographic differences. Florida is characterized by larger metropolitan areas and is more diverse in terms of races and ethnicity than Indiana.

In following the insights from previous studies on the housing market, we accounted for the fact that housing markets differ considerably between cities (see, e.g., Bajari and Kahn (2005)). Hence, most of our empirical study will define markets at the city level. For Florida, we focus on the cities Fort Lauderdale, Hollywood and Miami. For Indiana, we concentrate on Lafayette and West Lafayette. ${ }^{16}$

We gathered detailed information on foreclosures, home sales, housing characteristics

\footnotetext{
${ }^{16}$ We selected those specific cities as they were characterized by a sufficiently large number of foreclosure cases. Moreover, in order to ensure that we have sufficient information on foreclosures and sociodemographics, we merged the cities Lafayette and West Lafayette, which are referred to as Lafayette from here onward.
} 
and neighborhood demographics from a variety of sources. The county assessor's offices and the Board of Realtors in Indiana and Florida granted us temporary access to their Multiple Listing Service (MLS) system. The MLS service is a comprehensive database used by real estate agents, and it contains the characteristics of houses listed on the market. The database provides detailed information on house transactions in the real estate market, such as the address of the house, the original list price, the last listed price, the transaction price, number of days a house was listed on the market, the number of bedrooms, the number of bathrooms, if the house was on foreclosure, and other demographic information. ${ }^{17}$ Since we focus on residential housing, we eliminated houses without bedrooms from the database. Moreover, we extracted outliers and possible data entry errors by censoring the house size, number of bedrooms, and number of bathrooms at the 99th percentile. We also eliminated the bottom 1 percentile of sale prices. All prices are expressed in 2007 U.S. dollars using the S\&P/Case-Shiller Home Price Indices and the All-Transactions House Price Index, decomposed by regions and seasonally adjusted. The data were taken from the S\&P Dow Jones Indices LLC and the Federal Reserve Bank of St. Louis.

Our foreclosure data encompass information on pre-foreclosed houses (those at the "Notice of Default" stage) and post-foreclosure cases (those at the "Real Estate Owned" stage). The pre-foreclosures were provided by a company called RealtyTrac.com, which specializes on collecting foreclosure data throughout the United States. RealtyTrac.com collects data from legal documents that are submitted by lenders during the foreclosure process. ${ }^{18}$ The post-foreclosures were provided by RealtyTrac.com as well as the county offices. We received information on the address of the foreclosed property as well as the date of foreclosure. Socioeconomic data were taken from the U.S. Census Bureau

\footnotetext{
${ }^{17}$ To appreciate the strengths of this dataset it is useful to contrast it with the housing information from the 2000 Census of Population and Housing. In the census, home prices are self-reported and less reliable. Moreover, the prices are partitioned into only 23 mutually exclusive categories. The last six categories measured in 1,000s are 225, 275, 350,450, 625 and 875 . The classifications incorporate a loss of information compared to our data.

${ }^{18}$ Note, pre-foreclosures are not registered with the county offices.
} 
(the Department of Commerce) and categorized at the census tract level. We gathered information on the geographical areas in terms of the population's educational attainment, racial and ethnic composition, income and mortgage information. School quality information is retrieved from the U.S. Department of Education, Indiana Department of Education and Florida Department of Education. ${ }^{19}$ The data were merged by address using geocoding software.

Turning to a description of the data, Figure 5 shows the evolution of the average housing prices over time. While the price in Indiana dropped from 2002 to 2006 by close to 10 percent, it increased in Florida until 2004 and drastically fell thereafter by almost 20 percent. The sharply declining average price reflects part of the housing bubble burst. Figure 6 also shows the total number of foreclosures in Indiana and Florida. The number of foreclosures in Florida tripled from 2000 to 2003, declined for a short period and sharply increased after 2004. In contrast, Indiana foreclosures monotonically increased until 2006.

In comparing the evolution of prices with the number of foreclosures, it is interesting to see that drastically falling prices after 2003 were accompanied by a larger number of foreclosures in Indiana. In Florida, the evolution of prices was positively correlated with the number of foreclosures, lagged by one to two years. It should be kept in mind that those numbers represent unconditional correlations.

Next, we introduce the average housing characteristics and demographics for Indiana and Florida, as shown in Table 1. The variables are defined as follows: (1) Price: Final transaction price measured in 2007 dollars. (2) Origprice: Original listed price in 2007 dollars. (3) Listprice: Original listed price in 2007 dollars. (4) Size: size of the house in square footage. (5) Baths: Number of full and half bathrooms. (6) Bedr: Number of bedrooms. (7) Age: Age of the house. (8) DOM: Number of days the house was listed on the market. (9) Black: Percentage of black residents in the (census tract) neighborhood.

\footnotetext{
${ }^{19}$ Since only public schools are evaluated by those sources, the school data for Florida are not as powerful as for Indiana. Most highly ranked schools in Florida are private schools, and public schools receive relatively low scores with little variance. In contrast, Indiana has relatively few private schools, and the rating of public schools shows larger variation. We return to this aspect later in our empirical analysis.
} 
(10) Hispanic: Percentage of Hispanic residents in the (census tract) neighborhood. (11) White: Percentage of white residents in the (census tract) neighborhood. (12) Income: The median income in the (census tract) neighborhood. (13) SecondMortgage: The percentage of houses with a second mortgage. (14) Bachelor: Percentage of residents with at least a bachelor degree in the (census tract) neighborhood. (15) Florida: A dummy variable for houses located in Florida.

Interestingly, the average final transaction price in Florida is $\$ 338,608$, which is almost two and a half times higher than the final transaction price in Indiana, which amounts to $\$ 134,795 .^{20}$ The average house in Florida is 1,625 square feet and has two bedrooms and two bathrooms. The houses are on average 22 years old and were listed on the market for 106 days. The average house in Indiana is about the same size (1,696 square feet) and has two bathrooms and three bedrooms, but is only 14 years old. Houses in Indiana sold on average after 77 days, which is about 29 days faster than in Florida. The percentages of black and Hispanic populations are larger in Florida than in Indiana. The median income in Florida is $\$ 50,922$, which is about 20 percent higher than in Indiana. The unemployment rate in both areas is around 3 percent. In Florida, only 28 percent have a bachelor degree, compared to 38 percent in Indiana. The higher educational attainment in Indiana is related to the fact that Lafayette and West Lafayette are populated by many employees from Purdue University, as well as professionals from research labs, etc. In both states, around 74 percent of homeowners finance their homes with mortgages. A slightly higher portion of homeowners hold a second mortgage in Indiana (28 percent) compared to Florida (21 percent). A closer look at the second mortgage holders also shows that households across all sociodemographic areas rely on second mortgages (see, e.g., the Census of Population and Housing). Hence, the data descriptives does not show a specific pattern of second mortgage holders with respect to house values or income. We return to this point further below when we discuss the determinants of foreclosure.

Separate descriptive statistics for foreclosed and non-foreclosed homes are shown in

\footnotetext{
${ }^{20}$ We refer to the final transaction price simply as sale price or price onward.
} 
Table 2. The table provides the following interesting insights: The difference in prices for non-foreclosed homes $(\$ 339,179)$ and foreclosed homes $(\$ 241,171)$ in Florida amounts to $\$ 98,008$ or 29 percent. The corresponding difference in Indiana is $\$ 43,734$, which corresponds to 32 percent. Foreclosed houses are approximately 4 percent smaller in Florida and 15 percent smaller in Indiana than the average sold. Foreclosed houses have been listed for a shorter period of time in both areas. The listing period was 20 percent shorter in Florida, while it was 17 percent shorter in Indiana.

Figures 7 and 8 show the distributions of house sales and foreclosures along with the house prices. The density for foreclosures is widely distributed across house values, emphasizing the fact that different market segments were impacted by foreclosure. It should be noted, however, that the distributions of the homes sold as well as the foreclosures, are skewed to the right, i.e., the mass of the distributions is concentrated on lower house values. Moreover, in the lower end of the price distribution the frequency of foreclosure is relatively higher than the number of houses sold. This provides evidence that, below the average prices, relatively more houses were foreclosed than offered on the market for sale.

It is interesting to note that in Florida, the ratio of originally listed price and last listed price is five times higher for foreclosed houses than for non-foreclosed houses. This finding strongly suggests that owners of foreclosed houses are more impatient and in greater need for selling the house than owners of non-foreclosed houses. Moreover, this result is consistent with the fact that foreclosed houses are listed on the market for significantly fewer days. In Indiana, the corresponding difference is only two times higher.

The difference in the last listed price and the final transaction price is 3.03 percent (3.29 percent) for foreclosed (non-foreclosed) houses in Florida. In Indiana, the difference amounts to 5.01 percent and 3.50 percent, respectively. Hence, buyers of foreclosed houses did not engage in significantly more intense bargaining activities.

Next, we elaborate whether selection issues may be a valid concern when investigating the impact of foreclosure. For example, if the vast majority of foreclosures appear in lowincome areas and those areas are strongly affected by price changes due to unobserved 
variables, a potential selection issue might arise.

\subsection{Probit Model}

Using a probit model, we analyze if foreclosures follow a specific pattern with regard to sociodemographic characteristics. Indexing housing units by $j$, we establish a foreclosure dummy that takes on a value of $1\left(F C_{j, t}=1\right)$ if a house is under foreclosure in period $t$. Otherwise, the foreclosure dummy is set to $0\left(F C_{j, t}=0\right)$. A latent variable is formulated, where $F C_{j, t}^{*}>0$, if $F C_{j, t}=1$ and $F C_{j, t}^{*} \leq 0$, if $F C_{j, t}=0$. Note that for the sake of simplicity, we drop the $t$ subindex in the remainder of the study. The foreclosure regression is specified as follows: ${ }^{21}$

$$
\begin{gathered}
F C_{j}^{*}=a_{1} P_{j}+a_{2} \text { Size }_{j}+a_{3} \text { Income }_{j}+a_{4} \text { SecondMortgage }_{j}+a_{5} \text { Florida }_{j} \\
+\sum_{s=6}^{12} a_{s} Y(1995+s)_{j}+\nu_{j} .
\end{gathered}
$$

The variables follow the definitions introduced in the previous section, $Y($.$) denotes a$ year dummy variable and the error term $\nu$ is assumed to follow a normal distribution with mean zero and a constant variance.

We estimate Equation (1) by maximum likelihood, and Table 3 shows the calculated marginal effects. Interestingly, even though price, size and second mortgage are highly significant, the associated marginal effects are $-0.44 * e^{-07}, 0.69 * e^{-05}$ and $0.01 * e^{-02}$, respectively, and therefore close to zero. The results provide evidence that those variable have hardly any economic impact on the probability to foreclose and are not considered as determinants which strongly predict the probability of foreclosure. Hence, we cannot claim that foreclosure events follow a specific pattern. Our results rather provide evidence that households across different sociodemographics can be subject to foreclosure. Fore-

\footnotetext{
${ }^{21}$ We began with specifications characterized by a large number of regressors and iteratively eliminated regressors that had insignificant impacts.
} 
closures are realized across the entire home value, house size and income distributions and are equally likely with respect to realizations of those variables. This result is also supported by the summary statistics that foreclosures are realized across different market segments. Foreclosure occurs through unforeseen circumstances (such as medical bills and unemployment, among others) and is realized across different groups of the society independent of wealth and income. The significant parameter estimate on the Florida dummy variable is explained by the fact that our dataset encompasses more foreclosed houses in Florida compared to Indiana. To summarize, our probit results support the claim that selectivity issues are not a concern.

We would like to take a moment to further discuss the problem that foreclosures could still be correlated with other omitted variables or local economic shocks. We do not want to ignore or dismiss further shocks entering the relationship between foreclosures and prices; these could include such things as plant closings, which may drive both house prices and foreclosures. Further below, we perform a robustness check and include a foreclosure dummy that is supposed to extract remaining unobserved effects that are directly related to foreclosure. Since further common shocks such as plant shutdowns do not directly or fully tie into foreclosures, we will expect that those shocks would still be part of the residuals, or at least a large part of it. As shown below, the dummy extracts more than 90 percent of the unobserved quality component, i.e., the residual. Hence, even though common shocks might be present, most of our residuals will be directly related to foreclosure, and only a small portion would be left for other common shocks.

It should be noted that specific types of "forced sales" (other than foreclosures) are potentially endogenous to house price changes because homes are more likely to sale if house prices fall. In the context of foreclosures, however, exogenous unforeseen events such as income shocks are the primary reasons for homeowners to default on their payments. In case a house would be sold due to drastic losses in home values, this would be a forced sale, which is independent of foreclosure. Moreover, Figures 2 and 3 show for Florida that foreclosures rather precede price declines, but not the reverse. For Indiana, we observe a 
rather negative correlation between prices and foreclosures.

\section{The Model}

In the following, we describe the housing model based on an estimation technique as suggested by Bajari and Kahn (2005). ${ }^{22}$ We incorporate (unobserved) house-quality (which is determined by foreclosures) as a house-specific fixed effect. The estimator allows us to flexibly recover unobserved house-specific qualities as a house fixed effect from the residual. We perform a nonparametric estimation method, which does not require any distributional assumptions on the parameters and imposes less restrictive assumptions on the error term, such that the unobserved quality is captured by the residuals in a flexible fashion.

As mentioned above, we accounted for the fact that housing markets differ considerably between cities and define the housing markets at the city level. The model includes $m=1, \ldots, M$ geographic areas, and each area is characterized by $i=1, \ldots, I_{m}$ individuals and $j=1, \ldots, J_{m}$ housing units. For the sake of simplicity, we suppress the subindex $m$ in the remainder of this article. A home is assumed to be a bundle of three types of attributes: First, the physical housing attributes include the size, the age, the number of bedrooms and bathrooms and the number of days listed on the market. Second, the community or neighborhood attributes include the percentage of black and white households in the neighborhood, the percentage of college-educated households and the time (in minutes) to commute to work. Third are the quality attributes, which are observed by the consumer but unobserved by the econometrician.

We introduce a vector $x_{j}$ which encompasses physical and community attributes of a house $j$. The unobserved house quality is denoted by a scalar $\xi_{j}$, and the equilibrium price of the housing unit $p_{j}$ is determined by the interaction between buyers and sellers. The home price $p_{j}$ is characterized by a function $p_{m}$, which maps the observed and unobserved

\footnotetext{
${ }^{22}$ The description of our housing demand model follows Bajari and Kahn (2005).
} 
attributes into equilibrium prices:

$$
p_{j}=p_{m}\left(x_{j}, \xi_{j}\right)
$$

The utility that consumer $i$ receives for house $j$ is given by

$$
u_{i j}=u_{i}\left(x_{j}, \xi_{j}, c\right)
$$

which is a function of housing characteristics $\left(x_{j}, \xi_{j}\right)$ and a consumption of a composite commodity $c$ with a price normalized to 1 . Hence, the utility represents a flow of services rather than a discounted lifetime utility. In this case, $p_{m}$ is interpreted as the implicit rental value of a house. ${ }^{23}$ Households are rational utility maximizers who choose their preferred bundle of housing attributes given their income $y_{i}$. Product $j^{*}(i)$ is utility maximizing for individual $i$, if

$$
j^{*}(i)=\underset{j}{\arg \max } u_{i}\left(x_{j}, \xi_{j}, y_{i}-p_{m}\left(x_{j}, \xi_{j}\right)\right)
$$

where the budget constraint is substituted into the utility function.

Given that $x_{j, k}$ is a continuous variable for characteristic $k$ and that product $j^{*}$ is utility maximizing for household $i$, then the following first-order condition must hold:

$$
\begin{aligned}
& \frac{\partial u_{i}\left(x_{j^{*}}, \xi_{j^{*}}, y_{i}-p_{j^{*}}\right)}{\partial x_{j, k}}-\frac{\partial u_{i}\left(\left(x_{j^{*}}, \xi_{j^{*}}, y_{i}-p_{j^{*}}\right)\right.}{\partial c} \frac{\partial p_{m}\left(x_{j^{*}}, \xi_{j^{*}}\right)}{\partial x_{j, k}}=0, \\
& \frac{\frac{\partial u_{i}\left(x_{j^{*}}, \xi_{j^{*}}, y_{i}-p_{j^{*}}\right)}{\partial x_{j, k}}}{\frac{\partial u_{i}\left(\left(x_{j^{*},}, \xi_{\left.j^{*}, y_{i}-p_{j^{*}}\right)}\right.\right.}{\partial c}}=\frac{\partial p_{m}\left(x_{j^{*}}, \xi_{j^{*}}\right)}{\partial x_{j, k}},
\end{aligned}
$$

where equation (3) represents the condition that the marginal rate of substitution between a continuous characteristic and the composite commodity is equal to the partial derivative of the hedonic.

\footnotetext{
${ }^{23}$ Note, it is a well established fact that if utility is separable in time, static first-order conditions will be appropriate even in the context of durable goods (see also Bajari and Kahn (2005)).
} 
Consumer preferences are specified as follows:

$$
\begin{aligned}
u_{i j}= & \beta_{i, 1} \text { Size }_{j}+\beta_{i, 2} \text { Age }_{j}+\beta_{i, 3} \text { DOM }_{j}+\beta_{i, 4} \text { Bedr }_{j}+\beta_{i, 5} \text { Baths }_{j}+\beta_{i, 6} \text { Black }_{j}+\beta_{i, 7} \text { White }_{j} \\
& +\beta_{i, 8} \text { Bachelor }_{j}+\beta_{i, 9} \text { Commute }_{j}+\beta_{i, 10} \xi_{j}+c,
\end{aligned}
$$

where

$$
\begin{aligned}
& \beta_{i, k}=f_{k}\left(d_{i}\right)+\eta_{i, k}, \\
& E\left(\eta_{i} / d_{i}\right)=0 .
\end{aligned}
$$

Note, that equation (4) allows for unobserved house-specific vertical differentiation component, the $\xi_{j}$. It allows us to control for different qualities between foreclosed and non-foreclosed houses. It should be noted that $\xi$ will be picking up other unobserved, possibly horizontal, housing characteristics. We believe, however, that a vertical quality component is the most reasonable and plausible interpretation in our empirical framework. ${ }^{24}$ The $\left(\beta_{i, k}\right)$ are household-specific taste parameters or the random coefficient for characteristic $k{ }^{25}$ It should be noted that no extreme value error term enters the model. Moreover, for continuous characteristics, no parametric assumptions are needed about the distributions of $\xi$ and $\beta_{k}$.

\subsection{Estimation}

We estimate a pricing function using flexible, nonparametric methods based on the techniques suggested by Fan and Gijbels (1996). A unique set of implicit prices is estimated

\footnotetext{
${ }^{24}$ See also Bajari and Kahn (2005) for a similar argument. Later, we will test for the unobserved vertical quality component further.

${ }^{25}$ They can be retrieved using the observation $x_{j^{*}, k}$ chosen by each individual as described in Bajari and Kahn (2005). As shown in equation (5), the household preferences can be specified as a function $f_{k}$ of demographic characteristics $d_{i}$ (here, income, commute etc.). In general, random coefficients allow for more heterogeneity between consumers' preferences in valuing housing attributes, compared to standard logit or multinomial probit models, which assume that preferences are identical across households (see also Berry et al. (1995)) .
} 
for each household $i$ who chooses home $j_{i}^{*}$ in market $m$. The hedonic function, which is meant to capture the budget constraint faced by consumer $i$, is specified as follows:

$$
\begin{aligned}
p_{j}= & \gamma_{1, j^{*}} \text { Size }_{j}+\gamma_{2, j^{*}} \text { Age }_{j}+\gamma_{3, j^{*}} \text { DOM }_{j}+\gamma_{4, j^{*}} \text { Bedr }_{j}+\gamma_{5, j^{*}} \text { Baths }_{j}+\gamma_{6, j^{*}} \text { Black }_{j} \\
& +\gamma_{7, j^{*}} \text { White }_{j}+\gamma_{8, j^{*}} \text { Bachelor }_{j}+\gamma_{9, j^{*}} \text { Commute }_{j}+\sum_{s=10}^{16} \gamma_{s} Y(1991+s)_{j}+\xi_{j^{*}} .
\end{aligned}
$$

In accordance with the theoretical model and previous studies in this area, the endogenous variable $(p)$ represents the annual (rental) price for housing and the estimates represent the annual implicit prices or the annual willingness to pay for specific characteristics. ${ }^{26}$ Note that only housing and neighborhood characteristics $j$ enter. Unlike a linear regression, where the relationship between the dependent and independent variables is globally linear, the relationship here is only locally linear. Thus, the coefficients have a subscript $\gamma_{\cdot, j^{*}}$ to emphasize that they will be specific to a particular bundle of characteristics. ${ }^{27}$ In following Fan and Gijbels (1996), weighted least squares is used to estimate equation (6),

$$
\gamma_{j^{*}}=\operatorname{argmin}_{\gamma}(p-X \gamma)^{\prime} W(p-X \gamma)
$$

where $p$ is a vector of prices and $X$ is a matrix of regressors,

$$
W_{j^{*}}=\operatorname{diag}\left[K_{j, j^{*}}\left(x_{j}, x_{j^{*}}\right)\right],
$$

where $W=\operatorname{diag}\left[K_{h}\left(x_{j}-x_{j^{*}}\right)\right]$ is a matrix of kernel weights. The weights are a function of the distance between the characteristics of product $j^{*}$ and product $j$. Hence, the local linear regression assigns more weight to observations with characteristics close to $j^{*}$. The

\footnotetext{
${ }^{26}$ Following Bajari and Kahn $(2005,2008)$, we retrieve the rental price by multiplying the sale price with 0.0785 .

${ }^{27}$ We apply the standard assumption in the hedonic literature that unobserved product characteristics are independent of the observed product characteristics, see also Bajari and Kahn (2005). This is also a reasonable assumption also in our case, since foreclosures are realized across different demographics and house characteristics, as shown above. Hence, it is reasonable to assume that unobserved quality is uncorrelated with observed housing characteristics.
} 
estimates of equation (7) allow us to uncover the unobserved housing characteristic $\xi_{j}$ :

$$
\begin{aligned}
\xi_{j}= & p_{j}-\left[\gamma_{1, j^{*}} \text { Size }_{j}+\gamma_{2, j^{*}} \text { Age }_{j}+\gamma_{3, j^{*}} \text { DOM }_{j}+\gamma_{4, j^{*}} \text { Bedr }_{j}+\gamma_{5, j^{*}} \text { Baths }_{j}+\gamma_{6, j^{*}} \text { Black }_{j}\right. \\
& \left.+\gamma_{7, j^{*}} \text { White }_{j}+\gamma_{8, j^{*}} \text { Bachelor }_{j}+\gamma_{9, j^{*}} \text { Commute }_{j}+\sum_{s=10}^{16} \gamma_{s} Y(1991+s)_{j}\right] .
\end{aligned}
$$

Bajari and Kahn (2005) suggest using a diagonal kernel weighting matrix, i.e., a local polynomial (linear) kernel method. We followed their suggestion and chose the following normal kernel density function with a bandwith of $h=3$ :

$$
\begin{aligned}
& K(z)=\prod_{k=1}^{16} N\left(z_{k} / \hat{\sigma}_{k}^{2}\right), \\
& K_{h}(z)=K(z / h) / h .
\end{aligned}
$$

where $K$ is a product of standard normal distributions, denoted by $N$. For the k'th characteristic, the normal distribution is evaluated at $z_{k} / \hat{\sigma}_{k}^{2}$, where $\hat{\sigma}_{k}^{2}$ is the sample standard deviation of characteristic $k$.

\subsection{The Results}

We estimate equation (6) for four different markets, i.e., Fort Lauderdale (FL), Hollywood (FL), Miami (FL) and Lafayette (IN). The results are shown in Table 4. Most of the estimates are highly significant and their magnitude is comparable to earlier studies on the housing market (see, e.g., Bajari and Kahn (2008)).

The implicit price per square foot is the lowest in Indiana and is priced at $\$ 5.67$ per year. An additional square foot costs $\$ 11.98$ per year in Hollywood and it costs $\$ 23.14$ per year in Fort Lauderdale. ${ }^{28}$ Converting the annual implicit prices for square footage, we find

\footnotetext{
${ }^{28}$ Note, the estimates represent the annual implicit prices for an additional square foot. To convert this number into a total implicit price for square footage (not annual), we can use the results for the implicit prices from our hedonic regression, which is introduced further below. Applying a factor of 13, the implicit total price for characteristics obtained from the hedonic regression equation is equal to the annual implicit price for specific characteristics from estimating equation (6). This factor is applied to convert the annual implicit prices into total implicit prices.
} 
that the buyers' willingness to pay is $\$ 73.71, \$ 155.74$ and $\$ 300.82$ for an additional square foot in Indiana, Hollywood and Fort Lauderdale, respectively. The estimates confirm the notion that housing in the Midwest is significantly cheaper than in Florida, which is not surprising since the Midwest is ranked as one of the most inexpensive areas in the real estate market in the United States. As expected, the highest price for square footage is paid in Fort Lauderdale, which is reasonable, as this city was significantly more affected by the housing bubble and speculative investments. In general, the parameter estimate partly explains that houses in Florida are two and a half times more expensive than in Indiana. Moreover, the large and significant differences emphasizes the importance of accounting for geographic differences when estimating the implicit prices.

The parameter estimates for Age are significantly negative for Lafayette and Miami, indicating that older houses are sold for lower prices. An additional year lowers the rental price by $\$ 16.51$ in Lafayette and by $\$ 26.93$ in Miami. Hence, the sale price decreases by $\$ 215$ and $\$ 350$, respectively, if the house is one year older.

The number of days a house has been listed on the market has different implications depending on the regions. Conditional on selling a house, a further listing day on the market lowers the price in Lafayette, but increases the sale price in Florida by around \$73. Accounting for the fact that foreclosed houses are listed days for 17 fewer days on the market than non-foreclosed houses (see Table 2), it explains a price difference of $\$ 1,326$ between foreclosed and non-foreclosed houses. ${ }^{29}$ This difference is entirely attributed to owners of repossessed foreclosed homes selling sooner, which allows them to reinvest the capital of the sold house. Keeping the houses on the market for a longer period causes losses, as potential income from interest is foregone from investing the capital of the sold house elsewhere.

A further bedroom increases the annual price by $\$ 3,647$ in Hollywood, by $\$ 5,032$ in Fort Lauderdale, and by $\$ 9,731$. These numbers are equivalent to an increase in the value

\footnotetext{
${ }^{29}$ For further information on the duration of keeping houses on the market and how this affects prices, see also Levitt and Syverson (2008) and Genesove and Mayer (1997).
} 
of a home by $\$ 47,413, \$ 65,413, \$ 126,503$ respectively. Residents in Florida are willing to pay less for another bathroom than for another bedroom, while the opposite applies in Indiana.

Neighborhood demographics critically depend on the geographic location. While houses in black neighborhoods are less expensive (compared to Hispanic neighborhoods, our reference group) in Fort Lauderdale, they do not show a significant impact in Hollywood or in Indiana. Interestingly, the willingness to pay for white neighborhoods is positive in Hollywood, but negative in Fort Lauderdale. In general, the results indicate that Hispanic neighborhoods are more expensive in Fort Lauderdale than black or white neighborhoods. In Hollywood, white neighborhoods are more expensive, and in Indiana, the racial composition of neighborhoods has no impact on price.

Moreover, more educated neighborhoods are more expensive in Lafayette. A 20 percent improvement in the school performance increases the annual willingness to pay by $\$ 509$, which corresponds to an increase in the total house value by $\$ 6,604 .^{30}$ An reduction in commute time by one minute increases the house value by $\$ 1,547$ in Fort Lauderdlae and by $\$ 4,264$ in Miami.

In the following, we concentrate our attention to the main focus of this study and evaluate the impact of foreclosure on home values. Based on the regression results, we retrieve the unobserved house-specific quality components for foreclosed houses as suggested by equation (9). Figure 9 shows the distributions of the residuals along the house size distributions for Fort Lauderdale, Hollywood and Lafayette, respectively. The figures provide remarkable insights: A vast majority of the foreclosed homes are characterized by negative residuals, as illustrated by the quadratic marks. The negative residuals provide

\footnotetext{
${ }^{30}$ We did not incorporate the schoolscore for Florida since the schoolscore for Florida is not as informative as for Indiana. Most high-quality schools in Florida are private schools, and the U.S. Department of Education collects information only on public schools. The scores among public schools suffer from insufficient variation, as private schools usually achieve significantly higher scores, and private schools are more common in Florida. In Indiana, the proportion of private schools is smaller and the variation of school scores among public schools is much higher. Note, Bayer, McMillan and Rueben (2004) study of San Francisco's housing market in 1990 provides direct evidence that controlling for school quality adds little information.
} 
evidence that foreclosed homes are characterized by unobserved quality attributes and sold for lower prices. The annual price discounts of foreclosed homes for Fort Lauderdale, Hollywood and Indiana are $\$ 3,239, \$ 1,268$ and $\$ 1,831$, respectively. Those numbers correspond to total home value losses of $\$ 42,110$ in Fort Lauderdale, which corresponds to 12 percent of the average house price in Florida. In Hollywood, foreclosed homes lost \$16, 479 (or $4.7 \%$ of the house price in Florida) and houses in Lafayette lost on average $\$ 23,798$, which corresponds to 16.1 percent of the average house price in Indiana. We applied a robustness check to gain further insight on whether the (negative) residuals as shown in the figures mainly capture unobserved quality attributes associated with foreclosure or if other unobserved attributes, which are unrelated to foreclosure, enter the residuals. Therefore, we applied the same regression as shown in equation (6), but inserted a foreclosure dummy which is supposed to absorb any (omitted) quality deviations related to foreclosed houses. The estimation results are shown in Table 5, and the residuals are illustrated in Figure 10 where, again, the quadratic marks illustrate residuals of foreclosed houses. The figure provides remarkable evidence that the residuals of foreclosed homes are now much closer to zero, in contrast to Figure 9, where the residual was significantly more negative. More specifically, the average value residuals for foreclosed houses shifted (for Fort Lauderdale, Hollywood and Indiana, respectively) from formerly $-\$ 3,239,-\$ 1,268$ and $-\$ 1,831$ (when excluding the foreclosure dummy) to $\$ 10.74,-\$ 39.54$ and $-\$ 88.35$ after including a foreclosure dummy. Consequently, the inclusion of the foreclosure dummy absorbs a tremendous amount of the residuals of foreclosed homes. This result provides evidence that the residuals in the first regression are characterized to the most part by (omitted) quality attributes of foreclosed houses.

We also estimated equation (6) accounting for more heterogeneity between foreclosed houses. We separated the foreclosure impact on prices and distinguished between foreclosures at the lower and upper segment of the house values. We, therefore, classified foreclosures of houses that are smaller (larger) than the mean of the overall house size as LowForeclosure (HighForeclosure) events. If a house below (above) the median price 
is foreclosed, a Low (High) Foreclosure dummy takes on a value of 1 , otherwise it is 0 . We estimated the implicit price equation. The results remain qualitatively and quantitatively unchanged.

Next, we performed a further robustness check to test whether the residuals of foreclosed homes can be, for the most part, attributed to (unobserved) quality components. In case the residuals mostly represent quality components and foreclosed houses are characterized by lower quality, the residuals have to be significantly lower than the residuals of the non-foreclosed homes. The results of the residuals for non-foreclosed houses show that the average residuals for Fort Lauderdale, Hollywood and Indiana are $-\$ 310.84$, $\$ 195.23$ and $-\$ 14.81$, respectively, and those are considerably smaller than the residuals of the foreclosed homes, i.e., $-\$ 3,239,-\$ 1,268$ and $-\$ 1,831$, respectively. The residuals for non-foreclosed houses are 10 times smaller for Fort Lauderdale and Hollywood, as well as 100 times smaller for Lafayette. As mentioned earlier, the test provides evidence that large parts of the residuals are directly tied to foreclosure and captures unobserved quality characteristics of foreclosed houses. Only a minor percentage is attributed to other unobserved attributes or other exogenous shocks such as plant shutdowns, etc. Note that the remaining portion of residuals for non-foreclosed houses could also be related to neighborhood or spillover effects, i.e., houses in the neighborhood lose value since an area house was foreclosed. We will return to this aspect below. Moreover, it should be noted that the residuals for non-foreclosed homes are relatively small, which supports the good fit of the hedonic model explaining home prices.

Returning to Figure 9, it should be recognized that the negative residuals of the foreclosed houses are distributed along the entire house size distribution. Hence, foreclosure is a critical concern across different segments of the housing market. We further investigated the residuals of foreclosed homes to provide insight into the heterogeneous impact of foreclosure on housing prices in different housing market segments. We classified houses below (above) the mean of the house size distribution as members of the lower (upper) market segment. Table 6 shows that the impact of foreclosure across market segments 
shows strong geographic differences. In Fort Lauderdale, foreclosed houses in the lower market segment experienced a discount of $\$ 17,371$ (6.24\%), while houses in the upper segment lost $\$ 211,750(32.1 \%)$. The losses at the upper segment are immense and support public opinions that houses experienced large losses from speculative investments in the real estate markets at the upper segment of the housing distribution. In a similar vein, foreclosed houses in Hollywood also lost more at the upper segment $\$ 61,593$ (12.77 percent) than at the lower segment $\$ 6,068$ (2.75 percent). The losses, however, are considerably smaller than the losses experienced by homeowners in Fort Lauderdale. In contrast to these findings, foreclosed houses in Lafayette lost most of their value at the lower market segment of the house size distribution, $\$ 22,469$ (19.34\%), and experienced fewer losses on the upper market segment, $\$ 25,215$ (13.23\%). The finding that foreclosed houses in the lower market segment lost more in Indiana than in Florida is remarkable and indicates that the cross-price elasticities in Indiana are larger at the lower market segment than in Florida.

We applied the same procedure to evaluate the impact of foreclosures in neighborhoods characterized by low and high income (see Table 6). Our results show a considerable amount of heterogeneity for low- and high-income areas in Fort Lauderdale. While foreclosed homes located in low-income neighborhoods lost $\$ 28,336$ (10.2 percent), they lost $\$ 154,583$ (23.4 percent) in high-income areas (see Table 6). Surprising is the finding that foreclosed houses in Hollywood and Lafayette lost more in absolute and relative terms in lower-income neighborhoods than in wealthier neighborhoods (see Table 6). To summarize, it is interesting to note that foreclosed houses in Florida lost more in upperincome areas, while foreclosed houses in Indiana lost value in lower-income areas and in the smaller house size segment.

We employed further regression analyses to test if other specific neighborhood attributes i.e., family size, percentage of mortgage takers and percent below poverty level exert a heterogeneous impact on the value of foreclosed homes. We estimated equation (6) without and with a foreclosure dummy and then established the difference of the retrieved 
residuals for every foreclosed house. The difference in the residuals illustrates the loss for every foreclosed house. In a next step, we regressed the difference in the residuals on the specific neighborhood attributes. Table 7 shows that neighborhoods characterized by larger houses, lower incomes and low poverty suffered the most from home value losses. Note that the percentage of mortgage takers is insignificant.

We finally address the question of whether neighborhood effects exist, that is, did non-foreclosed houses experience losses as a response to other houses in the neighborhood being foreclosed? We establish a dummy variable $\left(N\right.$ eighborhood $\left.F C_{t}\right)$ that takes a value of 1 if a house was foreclosed in the neighborhood in year $t$, otherwise it takes a value of 0.31

In estimating the neighborhood foreclosure effects, we employ the same specification as shown in equation (6), but include the NeighborhoodFC dummy as an additional regressor. The specification looks as follows:

$$
\begin{aligned}
P_{j} & =\delta_{1} \text { Size }_{j}+\delta_{2} \text { Age }_{j}+\delta_{3} \text { DOM }_{j}+\delta_{4} \text { Bedr }_{j}+\delta_{5} \text { Baths }_{j}+\delta_{6} \text { Black }_{j} \\
& +\delta_{7} \text { White }_{j}+\delta_{8} \text { Bachelor }_{j}+\delta_{9} \text { Commute }_{j}+\delta_{10} \text { NeighborhoodFC }_{j}+\mu_{j} .
\end{aligned}
$$

Since we are interested in the ultimate impact of foreclosure on neighboring houses, we include only non-foreclosed houses in our estimation. We estimate the equations separately for Indiana and Florida. ${ }^{32}$ The estimation results are shown in Table 8 . The results for housing and neighborhood attributes are comparable to our earlier regression results shown in Table 4. Most interestingly, the NeighborhoodFC dummy turns out to be highly significant and negative. Non-foreclosed homes in Florida lose $\$ 216.78$ per year due to

\footnotetext{
${ }^{31}$ Recall that we drop the subscript $t$. We evaluate the neighborhood effect at a census tract level, which is the most appropriate and also highly disaggregated proxy in our dataset. We might miss out on capturing very specific types of neighborhood effects, where foreclosed houses are located next to non-foreclosed houses, but each house belongs to a different census tract. In this case, the estimated neighborhood foreclosure effect should be interpreted rather conservatively, as the estimates might potentially be underestimated.

${ }^{32}$ Note that since the NeighborhoodFC dummy is included in the estimation equation, we faced multicollinearity and singularity problems in the estimation procedure. Hence, we had to drop the year dummies and pool the observations across different cities in Florida.
} 
neighborhood effects, which is equivalent to an average loss of $\$ 2,818$ or 0.8 percent per house. Non-foreclosed homes in Indiana lose $\$ 531.70$ per year, or a total loss of $\$ 6,912$ or 4.7 percent. The results provide support for neighborhood effects and emphasize the overall concern that foreclosure is not constrained to foreclosed home themselves but also spreads out toward neighboring homes such that foreclosure becomes a nationwide concern. The finding that the neighborhood effects are larger in Indiana than in Florida is remarkable and is possibly related to our previous finding that foreclosure had a larger impact on the lower market segments in Indiana. Since more houses are offered on the market in the lower market segments, larger cross-price elasticities in those segments might translate into larger neighborhood effects.

\subsection{Robustness}

In following Rosen (1974) and Epple (1987), we perform a hedonic regression to see if our main results are supported given different estimation procedures. ${ }^{33}$ We regress the housing prices on housing characteristics, neighborhood demographics and a foreclosure dummy. Note that no sociodemographic variables enter the regression, since they might be acting as proxies for unobserved neighborhood characteristics (see Epple (1987)).

We run several hedonic regressions. Our first hedonic regression pools all observations across geographic regions and uses a dummy variable (Florida) to allow for state-specific differences. The specification is as follows:

$$
\begin{aligned}
& P_{j}=\alpha_{1} \text { Size }_{j}+\alpha_{2} A g e_{j}+\alpha_{3} D O M_{j}+\alpha_{4} B e d r_{j}+\alpha_{5} \text { Baths }_{j}+\alpha_{6} F C_{j}+\alpha_{7} \text { Black }_{j} \\
& +\alpha_{8} \text { White }_{j}+\alpha_{9} \text { Bachelor }_{j}+\alpha_{10} \text { Commute }_{j}+\alpha_{11} \text { Florida }_{j}+\sum_{s=12}^{18} \alpha_{s} Y(1989+s)_{j}+\omega_{j} .
\end{aligned}
$$

\footnotetext{
${ }^{33}$ Hedonic regressions are one of the most commonly used techniques focusing on the housing market, with seminal contributions by Rosen (1974) and Epple (1987). See also Rosen (1974), Epple (1987) and Ekeland, Heckman and Nesheim (2004) for further information on hedonic regressions.
} 
Assuming a normal distribution on the error term $\omega$, we estimate this equation by ordinary least squares (OLS). The estimation results are shown in Table 9, Column 1. We also estimated equation (11) separately for Florida and Indiana. The results are shown in Table 9, Columns 2 and 3, which we concentrate on in our following discussion.

While home buyers are willing to pay $\$ 184.15$ per additional square foot in Florida, they are willing to pay only $\$ 72.39$ for the additional space in Indiana. The results also show differences in the willingness to pay for the age of the house. An additional year of the age of a house reduces the price in Indiana by $\$ 120.54$, but it increases the price in Florida. This result is different than what we reported above.

An additional bedroom increases the house price in Florida by $\$ 48,624$, and an additional bathroom is worth $\$ 16,291$. Most interestingly in our context is the finding that foreclosure reduces the home price in Florida on average by $\$ 34,929$ (10\%), and lowers the price in Indiana on average by $\$ 24,887$ (19\%). Hence, foreclosure has a higher absolute impact on houses in Florida, but a lower impact in relative terms. Racial demographics turned out to be significant for Florida. An increase in the black or white neighborhood population by 1 percentage point lowers the price by $\$ 2,094$ and $\$ 899$, respectively, compared to the Hispanic reference group. The estimate for the schoolscore for Indiana shows that a one point increase, which is equivalent to a 20 percent increase in school quality, is worth $\$ 7,422$. Home buyers in Florida are willing to pay an additional $\$ 2,184$ if the percentage of homeowners in the neighborhood with bachelor's degrees increases by one percentage point. In Indiana, the willingness to pay is negative, which might be related to the fact that a large part of the population in Lafayette achieved high levels of education and they mostly live in suburban areas close to the university or research labs, and these areas are more inexpensive than the downtown area. A reduction in commuting time by one minute increases the price in Florida by $\$ 4,306$ and in Indiana by $\$ 507$. The time dummies turn out to be significant, and the adjusted R-square is 90 percent, confirming a very good fit.

We also separate the foreclosure impact on prices and distinguished between foreclo- 
sures at the lower and upper segment of the house values. Hence, we distinguish between foreclosures above and below the mean sale price. If a house below (above) the mean price is foreclosed, a Low (High) Foreclosure dummy takes on a value of 1, otherwise it is 0 . As shown in Table 9, Columns 5 and 6, we find that foreclosure has a significant impact on prices in Indiana and Florida at the lower market segment, reducing the prices by $\$ 31,904$ and $\$ 37,399$, respectively. In contrast, foreclosure has a price reducing impact on the upper market segment only in Florida $(\$ 28,230)$.

As a further robustness check, we evaluate the implicit prices at the city level. Hence, we run the hedonic regression as shown in equation (11) separately for Miami (FL), Hollywood (FL), and Fort Lauderdale (FL). ${ }^{34}$ The results are shown in Table 10, which confirm the previously discussed results. With regard to the low and high foreclosure dummies, it is interesting to note that foreclosure has a significant impact only in Miami, where it reduces the house values by $\$ 27,150$. In contrast, Hollywood and Fort Lauderdale experience price discounts only at the upper market segment, where prices declined by $\$ 37,253$ and $\$ 104,9544$, respectively. In general, the estimates turn out to be highly significant, and the variables explain a high proportion of the variance in the price. Moreover, the estimates confirm the robustness of our previous estimation results.

\section{Conclusion}

Our study provides evidence that foreclosed homes lost significant amounts in value. We find that more than 90 percent of the foreclosure effect on house prices is explained by the fact that foreclosed houses are characterized by lower quality. Our results also show that the discounts are characterized by a significant degree of heterogeneity. In much of Florida, foreclosed houses lost a significant value at the upper part of the house size and income distributions. In contrast, foreclosed houses in Lafayette, Indiana, lost most of the value at the lower market segment of the house size and income distributions,

\footnotetext{
${ }^{34}$ Our observations for Indiana mostly consist of two cities (Lafayette and West Lafayette) and a further decomposition is not necessary.
} 
but experienced fewer losses at the upper market segment. For example, while foreclosed homes in Fort Lauderdale (FL) lost on average $\$ 42,110$ in value (12 percent of the average Florida home value), homes in Lafayette (IN) lost on average $\$ 23,798$, which corresponds to 16.1 percent of the average house price in Indiana.

We also show that non-foreclosed houses agonized losses (from 0.8 to 4.7 percent) due to the fact that other houses in the neighborhood were foreclosed. The results provide support for neighborhood effects and provide support for the overall concern expressed by many homeowners, politicians and policy makers that foreclosure is not constrained to foreclosed homes, but also spreads toward neighboring homes. As mentioned in the introduction, many politicians, economists and policy makers claimed that the recovery of the financial crisis and the economy critically hinges on the recuperation of the housing market. Our study provides insights into the magnitude of home value losses and the heterogeneous impact of foreclosure that might be insightful to policy makers and politicians in incorporating policy interventions for the housing markets. Our estimation results suggest that the extent to which homeowners were affected by foreclosure depends on the geographic regions and also had an impact across income and house values. The significant neighborhood effects provide evidence that foreclosure is a nationwide concern since the entire real estate market is potentially affected by the price discounts. This finding supports the argument that financial support for homeowners facing potential foreclosure problems is beneficial for the entire economy. We have also shown that potential financial support could target different groups depending on the geographic region.

For future research, it would be interesting to concentrate on other areas that were also affected by the housing bubble, e.g., California, and to test if foreclosed home values depreciated similarly as in Florida. This task goes beyond the scope of this study. 


\section{References}

Ackerberg, D. and M. Rysman , 2002, " Unobserved Product Differentiation in Discrete Choice Models: Estimating Price Elasticities and Welfare Effects, NBER working paper.

Apgar, W.C. and M. Duda, and R. Gorey, 2005, "The Municipal Cost of Foreclosures: A Chicago Case Study," Mimeo.

Bajari, P. and L. Benkard, 2005, "Demand Estimation with Heterogeneous Consumers and Unobserved Product Characteristics," Journal of Political Economy, Vol. 113, No. 6, pp. 1239-1276.

Bajari, P. and M. Kahn, 2005, "Estimating Housing Demand with an Application to Explaining Racial Segregation in Cities," Journal of Business and Economic Statistics, Vol. 23, No. 1, pp. 20-33.

Bajari, P. and M. Kahn, 2008, "Estimating Hedonic Models of Consumer Demand with an Application to Urban Sprawl," in: Baranzini, A. et al., "Hedonic Methods in Housing Markets".

Bayer, P., R. McMillan and K. Rueben, 2004, "The Causes and Consequences of Residential Segregation: An Equilibrium Analysis of Neighborhood Sorting," Working Paper, Yale University.

Berry, S., 1994, "Estimating Discrete Choice Models of Product Differentiation," Rand Journal of Economics, Vol. 25, pp. 242-262.

Berry, S., J. Levinsohn and A. Pakes, 1995, "Automobile Prices in Market Equilibrium," Econometrica, Vol. 63, pp. 841-889.

Calomiris, C. and S. Longhofer, and W. Miles, 2008, "The Foreclosure-House Price Nexus: Lessons from the 2007-2009 Housing Turmoil," National Bureau of Economic Research Working Paper 14294.

Campbell, J. and S. Giglio and P. Pathak, 2011, "Forced Sales and House Prices," American Economic Review, Vol. 101, No. 5, pp. 2108-2131.

Cutler, D. and E. Glaeser, 1997, "Are Ghettos Good or Bad?," Quarterly Journal of Economics, Vol. 112, pp. 827-972.

Cutler, D. and E. Glaeser, 1999, "The Rise and Decline of the American Ghetto," Journal of Political Economy, Vol. 112, pp. 455-506.

Ekeland, I., J. Heckman and L. Nesheim, 2004, "Identification and Estimation of Hedonic Models," Journal of Political Economy, Vol. 112, N. 1/2, pp. 60-109.

Epple, D. 1987, "Hedonic Prices and Implicit Markets: Estimating Demand and Supply Functions for Differentiated Products," Journal of Political Economy, Vol. 95, No. 1, pp. 59-80. 
Epple, D. and H. Sieg, 1999, "Estimating Equilibrium Models of Local Jurisdictions," Journal of Political Economy, Vol. 107, No.4, pp. 645-681.

Fan, J. and I. Gijbels, 1996, "Local Polynomial Modeling and Its Applications (Monographs on Statistics and Applied Probability," Vol 66, CRC Press.

Foote, C. and K. Gerardi, and P. Willen, 2008, "Negative Equity and Foreclosure: Theory and Evidence," Journal of Urban Economics, Vol. 64, pp. 234-245.

Genesove, D. and C.J. Mayer, 1997, "Equity and Time to Sale in the Real Estate Market," American Economic Review, Vol. 87, No. 3, pp. 255-269.

Goolsbee, A. and A. Petrin, 2004, "The Consumer Gains from Direct Broadcast Satellites and the Competition with Cable TV," Econometrica, Vol. 72, No. 2, pp. 351-381.

Harding, J.P. and E. Rosenblatt and V. Yao, 2008, "The Contagion Effect of Foreclosed Properties," Mimeo.

Hartley, D., 2010, "The Effects of Foreclosures on Owner-Occupied Housing Prices: Supply or Dis-Amenity?," Federal Reserve Bank of Cleveland, Working Paper.

Immergluck, D. and G. Smith, 2005, "There Goes the Neighborhood: The Effect of Single-Family Mortgage Foreclosures on Property Values," Mimeo.

Immergluck, D. and G. Smith, 2006, "The Impact of Single-Family Mortgage Foreclosures on Neighborhood Crime," Housing Studies, Vol. 21, No. 6, pp. 851-866.

Mian, A. and A. Sufi, 2014, "House of Debt," The University of Chicago Press.

Mian, A. and A. Sufi and F. Trebbi, 2014, "Foreclosures, House Prices, and the Real Economy," Journal of Finance, forthcoming.

Levitt, S. and C. Syverson, 2008, "Market Distortions When Agents Are Better Informed: The Value of Information in Real Estate Transactions," Review of Economics and Statistics, Vol. 90, No. 4, pp. 599-611.

Nevo, A., 2001, "Measuring Market Power in the Ready-to-Eat Cereal Industry," Econometrica, Vol. 69, No. 2, pp. 307-342.

Petrin, A., 2002, "Quantifying the Benefits of New Products: The Case of the Minivan," Journal of Political Economy, Vol. 110, No. 4, pp. 705-729.

Rosen, S., 1974, "Hedonic Prices and Implicit Markets: Product Differentiation in Pure Competition," Journal of Political Economy, Vol. 82, pp. 34-55.

Sieg, H., K. Smith and S. Banzhaf and R. Walsh, 2002, "Interjurisdictional Housing Prices in Locational Equilibrium," Journal of Urban Economics, Vol. 52, No. 1, pp. 131-153. 


\section{A Appendix: Tables}

Table 1: Summary Statistics: Florida and Indiana, 2000-2008

\begin{tabular}{l|ccc|ccc}
\hline \hline \multirow{2}{*}{ Variable } & \multicolumn{3}{|c|}{ Florida } & \multicolumn{3}{c}{ Indiana } \\
\hline Price & Mean & Min & Max & Mean & Min & Max \\
Size & 338,608 & 30,000 & $2,142,300$ & 134,795 & 30,000 & 451,400 \\
Baths & 1,625 & 100 & 10,000 & 1,696 & 480 & 9,649 \\
Bedr & 2.09 & 0 & 4 & 2.15 & 0 & 4 \\
Age & 2.37 & 0 & 4 & 3.13 & 0 & 4 \\
DOM & 22.23 & 0 & 143 & 14.13 & 0 & 207 \\
Black* (in \%) & 106.28 & 0 & 600 & 77.73 & 0 & 593 \\
Hispanic* (in \%) & 10.66 & 0 & 97 & 2.13 & 0 & 6 \\
White* (in \%) & 16.08 & 0 & 49 & 4.76 & 0 & 20 \\
Schoolscore* & 67.33 & 1 & 99 & 87.33 & 63 & 98 \\
Bachelor* (in \%) & 2.84 & 1 & 4.50 & 3.15 & 1 & 5 \\
Commute* (in minutes) & 28.68 & 2.50 & 66.80 & 38.45 & 16.80 & 50.80 \\
Income* (median) & 27.67 & 13 & 88.60 & 19.74 & 13 & 58.90 \\
Below Poverty* (in \%) & 50,922 & 0 & 147,348 & 42,844 & 8,853 & 62,991 \\
Unemployed* (in \%) & 17.47 & 0 & 69.70 & 20.56 & 2.60 & 75 \\
Mortgage* (in \%) & 2.97 & 0 & 56.30 & 3.14 & 1.10 & 9.90 \\
Second Mortgage* (in \%) & 73.66 & 0 & 100 & 74.24 & 30.40 & 100 \\
\hline Observations & 21.34 & 0 & 100 & 27.81 & 14.60 & 43.60 \\
\hline \hline
\end{tabular}

Table 1 shows the summary statistics for Florida and Indiana. Prices are adjusted to 2007 using the regional S\&P/Case-

Shiller Home Price Index. *Variables relate to census tract levels. Sources: RealtyTrac.com and Multiple Listing Service. 
Table 2: Summary Statistics: Florida and Indiana, 2000-2008

\begin{tabular}{l|cc|cc}
\hline \hline \multirow{2}{*}{} & \multicolumn{2}{|c|}{ Florida } & \multicolumn{2}{c}{ Indiana } \\
Variable & FC=1 & FC=0 & FC=1 & FC=0 \\
& Mean & Mean & Mean & Mean \\
\hline Price & 241,171 & 339,179 & 90,438 & 136,746 \\
Listprice & 253,699 & 352,682 & 93,012 & 148,606 \\
Origprice & 261,753 & 358,142 & 94,961 & 151,920 \\
Size & 1,558 & 1,626 & 1,451 & 1,699 \\
Baths & 2.00 & 2.09 & 1.82 & 2.17 \\
Bedr & 2.02 & 2.37 & 2.86 & 3.15 \\
Age & 29.32 & 22.19 & 6.86 & 14.47 \\
DOM & 84.92 & 106.40 & 64.88 & 77.93 \\
Black* (in \%) & 26.20 & 10.56 & 2.29 & 2.12 \\
Hispanic* (in \%) & 17.43 & 16.07 & 5.99 & 4.70 \\
White* (in \%) & 49.13 & 67.44 & 85.86 & 87.41 \\
Schoolscore* & 2.86 & 2.84 & 2.80 & 3.17 \\
Bachelor* (in \%) & 366,479 & & 24,761 & \\
Commute* (in minutes) & 22.87 & 28.71 & 34.47 & 38.60 \\
Income* (median) & 28.41 & 27.66 & 19.80 & 19.74 \\
Below Poverty* (in \%) & 46,577 & 50,947 & 43,745 & 42,817 \\
Unemployed* (in \%) & 21.13 & 17.44 & 19.91 & 20.57 \\
Mortgage* (in \%) & 4.03 & 2.96 & 3.31 & 3.13 \\
Second Mortgage* (in \%) & 22.23 & 21.34 & 27.60 & 27.82 \\
(Origprice-Listprice/Origprice)*100 & 1.98 & 0.38 & 4.64 & 1.98 \\
(Listprice-Price/Listprice)*100 & 3.03 & 3.29 & 5.01 & 3.50 \\
\hline \hline Observations & 53.63 & 77.86 & 74.13 \\
\hline \hline
\end{tabular}

Prices are adjusted to 2007 using the regional S\&P/Case-Shiller Home Price Index. *Variables are based on census tract levels. Sources: RealtyTrac.com and Multiple Listing Service. 
Table 3: Estimation Results of the Probit Model

\begin{tabular}{lc}
\hline \hline $\begin{array}{l}\text { Endogenous Variable: } \\
\text { Variable }\end{array}$ & $\begin{array}{c}\text { Foreclosure Dummy } \\
\text { Marginal Effects }\end{array}$ \\
\hline Price & $-0.44^{*} e^{-07}$ \\
& $\left(0.22^{*} e^{-08}\right)^{* * *}$ \\
Size & $0.69^{*} e^{-05}$ \\
& $\left(0.71^{*} e^{-06}\right)^{* * *}$ \\
Income & $0.42^{*} e^{-08}$ \\
& $\left(2.31^{*} e^{-08}\right)$ \\
Second Mortgage & $0.01^{*} e^{-02}$ \\
& $\left(0.003^{*} e^{-02}\right)^{* * *}$ \\
Florida & 0.003 \\
& $\left(0.06^{*} e^{-02}\right)^{* * *}$ \\
Y2001 & -0.0003 \\
& $(0.002)$ \\
Y2002 & 0.008 \\
& $(0.003)^{* * *}$ \\
Y2003 & 0.007 \\
& $(0.002)^{* * *}$ \\
Y2004 & 0.003 \\
Y2005 & $(0.002)^{*}$ \\
Y2006 & -0.002 \\
Y2007 & $(0.001)^{* *}$ \\
& -0.001 \\
\hline \hline & $(0.001)$ \\
& 0.012 \\
& $(0.004)^{* * *}$ \\
\hline
\end{tabular}

Table 3 displays the marginal effects of the probit model shown in equation (1). The dependent variable is the Foreclosure dummy. The standard errors are shown in parentheses below the parameter estimates, and ${ }^{* * *},{ }^{* *}$ and ${ }^{*}$ denote $99 \%, 95 \%$ and $90 \%$ levels of significance, respectively. 
Table 4: Estimation Results of the Demand Model: No FC Dummy

\begin{tabular}{|c|c|c|c|c|}
\hline $\begin{array}{l}\text { Endogenous Variable: } \mathrm{p} \\
\text { Variable }\end{array}$ & $\begin{array}{l}\text { Lafayette } \\
\text { (1) }\end{array}$ & $\begin{array}{c}\text { Hollywood } \\
(2)\end{array}$ & $\begin{array}{l}\text { Ft. Laud. } \\
\text { (3) }\end{array}$ & $\begin{array}{c}\text { Miami } \\
(4)\end{array}$ \\
\hline Size & 5.67 & 11.98 & 23.14 & 7.54 \\
\hline & $(0.19)^{* * *}$ & $(1.18)^{* * *}$ & $(2.86)^{* * *}$ & $(0.44)^{* * *}$ \\
\hline Age & $\begin{array}{l}-16.51 \\
(7.59)^{* *}\end{array}$ & $\begin{array}{c}6.64 \\
(11.40)\end{array}$ & $\begin{array}{l}-64.01 \\
(75.41)\end{array}$ & $\begin{array}{c}-26.93 \\
(10.69)^{* *}\end{array}$ \\
\hline DOM & $\begin{array}{l}-1.03 \\
(0.70)^{*}\end{array}$ & $\begin{array}{c}2.83 \\
(1.88)^{* *}\end{array}$ & $\begin{array}{c}7.30 \\
(3.08)^{* * *}\end{array}$ & $\begin{array}{c}6.35 \\
(1.18)^{* * *}\end{array}$ \\
\hline Bedr & $\begin{array}{c}23.79 \\
(207.10)\end{array}$ & $\begin{array}{c}3,647.19 \\
(369.35)^{* * *}\end{array}$ & $\begin{array}{c}5,031.79 \\
(560.21)^{* * *}\end{array}$ & $\begin{array}{c}9,731.21 \\
(724.84)^{* * *}\end{array}$ \\
\hline Baths & $\begin{array}{c}1,413.07 \\
(295.13)^{* * *}\end{array}$ & $\begin{array}{c}750.96 \\
(217.66)^{* * *}\end{array}$ & $\begin{array}{c}2,218.45 \\
(967.29)^{* * *}\end{array}$ & $\begin{array}{c}735.23 \\
(231.09)^{* * *}\end{array}$ \\
\hline Black & $\begin{array}{c}272.66 \\
(318.90)\end{array}$ & $\begin{array}{l}14.85 \\
(24.79)\end{array}$ & $\begin{array}{l}-117.39 \\
(89.65)^{* *}\end{array}$ & $\begin{array}{c}17.27 \\
(17.82)\end{array}$ \\
\hline White & $\begin{array}{c}6.64 \\
(7.03)\end{array}$ & $\begin{array}{c}84.96 \\
(24.11)^{* * *}\end{array}$ & $\begin{array}{c}-293.91 \\
(86.66)^{* * *}\end{array}$ & $\begin{array}{c}200.55 \\
(36.30)^{* * *}\end{array}$ \\
\hline Schoolscore & $\begin{array}{c}508.89 \\
(108.41)^{* * *}\end{array}$ & & & \\
\hline Bachelor & $\begin{array}{c}-54.88 \\
(29.09)^{* *}\end{array}$ & $\begin{array}{l}-116.52 \\
(38.69)^{* * *}\end{array}$ & $\begin{array}{c}753.51 \\
(82.15)^{* * *}\end{array}$ & $\begin{array}{l}-13.53 \\
(10.52)\end{array}$ \\
\hline Commute & $\begin{array}{c}-36.67 \\
(22.76)^{* *}\end{array}$ & $\begin{array}{c}-426.81 \\
(113.46)^{* * *}\end{array}$ & $\begin{array}{l}-119.37 \\
(129.51)\end{array}$ & $\begin{array}{c}-328.99 \\
(47.67)^{* * *}\end{array}$ \\
\hline Y2001 & $\begin{array}{c}560.59 \\
(327.50)^{* *}\end{array}$ & $\begin{array}{l}-1846.36 \\
(646.38)^{* * *}\end{array}$ & $\begin{array}{c}-16,462.09 \\
(6,569.21)^{* * *}\end{array}$ & \\
\hline Y2002 & $\begin{array}{l}-128.91 \\
(165.65)\end{array}$ & $\begin{array}{c}1,550.04 \\
(828.57)^{* *}\end{array}$ & $\begin{array}{c}-6,468.43 \\
(5,036.02)^{*}\end{array}$ & $\begin{array}{c}-9,351.10 \\
(2,124.32)^{* * *}\end{array}$ \\
\hline Y2003 & $\begin{array}{l}-225.98 \\
(252.37)\end{array}$ & $\begin{array}{c}2,465.98 \\
(755.77)^{* * *}\end{array}$ & $\begin{array}{c}-6,240.72 \\
(5,211.54)^{*}\end{array}$ & $\begin{array}{c}-8,532.54 \\
(2,129.90)^{* * *}\end{array}$ \\
\hline Y2004 & $\begin{array}{c}-969.51 \\
(159.16)^{* * *}\end{array}$ & $\begin{array}{l}2843.72 \\
(608.31)^{* * *}\end{array}$ & $\begin{array}{c}-6723.78 \\
(5,728.45)^{*}\end{array}$ & $\begin{array}{c}-9,381.11 \\
(2,379.12)^{* * *}\end{array}$ \\
\hline Y2005 & $\begin{array}{l}-1,095.78 \\
(143.35)^{* * *}\end{array}$ & $\begin{array}{c}3,148.06 \\
(583.95)^{* * *}\end{array}$ & $\begin{array}{l}-6,898.88 \\
(6,334.47)\end{array}$ & $\begin{array}{c}-11,193.33 \\
(2,650.97)^{* * *}\end{array}$ \\
\hline Y2006 & $\begin{array}{c}-1,518.37 \\
(128.69)^{* * *}\end{array}$ & $\begin{array}{l}1,056.77 \\
(812.74)\end{array}$ & $\begin{array}{c}-9,768.08 \\
(6825.66)^{*}\end{array}$ & $\begin{array}{c}-13,630.10 \\
(2,925.71)^{* * *}\end{array}$ \\
\hline Y2007 & $\begin{array}{c}-1,597.75 \\
(140.83)^{* * *}\end{array}$ & $\begin{array}{l}-223.97 \\
(995.53)\end{array}$ & $\begin{array}{c}-13,186.95 \\
(7,049.44)^{* *}\end{array}$ & $\begin{array}{c}-13,394.24 \\
(2,942.87)^{* * *}\end{array}$ \\
\hline Adj. R-Square & 0.95 & 0.96 & 0.98 & 0.98 \\
\hline Observations & 1,958 & 2,876 & 5,775 & 52,751 \\
\hline
\end{tabular}

Table 4 shows the estimation results of the hedonic price function as shown in equation (6). The dependent variable is the house price. The model has been estimated nonparametrically using weighted least squares. The standard errors are shown in parentheses below the parameter estimates, and ${ }^{* * *},{ }^{* *}$ and ${ }^{*}$ denote $99 \%, 95 \%$ and $90 \%$ levels of significance, respectively. 
Table 5: Estimation Results of the Demand Model: With FC Dummy

\begin{tabular}{|c|c|c|c|c|}
\hline $\begin{array}{l}\text { Endogenous Variable: } \mathrm{p} \\
\text { Variable }\end{array}$ & $\begin{array}{l}\text { Lafayette } \\
(1)\end{array}$ & $\begin{array}{c}\text { Hollywood } \\
(2)\end{array}$ & $\begin{array}{l}\text { Ft. Laud. } \\
\text { (3) }\end{array}$ & $\begin{array}{c}\text { Miami } \\
(4)\end{array}$ \\
\hline Size & $\begin{array}{c}5.66 \\
(0.21)^{* * *}\end{array}$ & $\begin{array}{c}12.02 \\
(1.20)^{* * *}\end{array}$ & $\begin{array}{c}23.22 \\
(3.13)^{* * *}\end{array}$ & $\begin{array}{c}7.52 \\
(0.48)^{* * *}\end{array}$ \\
\hline Age & $\begin{array}{l}-15.38 \\
(7.59)^{* *}\end{array}$ & $\begin{array}{c}7.66 \\
(13.54)\end{array}$ & $\begin{array}{l}-64.46 \\
(75.67)\end{array}$ & $\begin{array}{c}-26.85 \\
(10.68)^{* *}\end{array}$ \\
\hline DOM & $\begin{array}{l}-1.11 \\
(0.72)^{* *}\end{array}$ & $\begin{array}{c}2.76 \\
(2.39)^{*}\end{array}$ & $\begin{array}{c}6.95 \\
(3.08)^{* * *}\end{array}$ & $\begin{array}{c}6.39 \\
(1.18)^{* * *}\end{array}$ \\
\hline Bedr & $\begin{array}{c}41.95 \\
(223.78)\end{array}$ & $\begin{array}{c}3,621.15 \\
(362.99)^{* * *}\end{array}$ & $\begin{array}{c}4,998.33 \\
(568.38)^{* * *}\end{array}$ & $\begin{array}{c}9,717.47 \\
(753.34)^{* * *}\end{array}$ \\
\hline Baths & $\begin{array}{c}1,458.49 \\
(336.59)^{* * *}\end{array}$ & $\begin{array}{c}760.02 \\
(263.94)^{* * *}\end{array}$ & $\begin{array}{c}2,218.84 \\
(995.82)^{* * *}\end{array}$ & $\begin{array}{c}737.82 \\
(237.19)^{* * *}\end{array}$ \\
\hline Foreclosure & $\begin{array}{l}-1,915.15 \\
(290.31)^{* * *}\end{array}$ & $\begin{array}{l}-764.47 \\
(879.67)\end{array}$ & $\begin{array}{c}-3,980.26 \\
(1,489.74)^{* * *}\end{array}$ & $\begin{array}{c}-1,417.90 \\
(295.36)^{* * *}\end{array}$ \\
\hline Black & $\begin{array}{c}351.22 \\
(308.15)\end{array}$ & $\begin{array}{l}15.72 \\
(24.68)\end{array}$ & $\begin{array}{l}-113.79 \\
(89.49)^{*}\end{array}$ & $\begin{array}{c}16.67 \\
(17.21)\end{array}$ \\
\hline White & $\begin{array}{c}6.78 \\
(8.76)\end{array}$ & $\begin{array}{c}86.07 \\
(23.85)^{* * *}\end{array}$ & $\begin{array}{c}-291.70 \\
(86.86)^{* * *}\end{array}$ & $\begin{array}{c}200.05 \\
(36.99)^{* * *}\end{array}$ \\
\hline Schoolscore & $\begin{array}{c}508.89 \\
(108.41)^{* * *}\end{array}$ & & & \\
\hline Bachelor & $\begin{array}{c}-61.21 \\
(27.64)^{* * *}\end{array}$ & $\begin{array}{l}-118.17 \\
(39.05)^{* * *}\end{array}$ & $\begin{array}{l}752.69 \\
(11.24)\end{array}$ & -13.12 \\
\hline Commute & $\begin{array}{c}-41.39 \\
(22.02)^{* *}\end{array}$ & $\begin{array}{c}-430.28 \\
(114.67)^{* * *}\end{array}$ & $\begin{array}{l}-113.96 \\
(129.94)\end{array}$ & $\begin{array}{c}-329.18 \\
(49.22)^{* * *}\end{array}$ \\
\hline Y2001 & $\begin{array}{c}562.07 \\
(327.18)^{* *}\end{array}$ & $\begin{array}{l}-1,624.99 \\
(977.540)^{* *}\end{array}$ & $\begin{array}{c}-16,611.52 \\
(6,586.97)^{* * *}\end{array}$ & \\
\hline Y2002 & $\begin{array}{c}-126.69 \\
(165.2104691)\end{array}$ & $\begin{array}{c}1,574.43 \\
(835.82)^{* *}\end{array}$ & $\begin{array}{l}-6,715.16 \\
(5,156.38)^{*}\end{array}$ & $\begin{array}{c}-9,261.81 \\
(2,168.80)^{* * *}\end{array}$ \\
\hline Y2003 & $\begin{array}{l}-222.81 \\
(251.63)\end{array}$ & $\begin{array}{c}2,459.24 \\
(763.39)^{* * *}\end{array}$ & $\begin{array}{c}-6,497.53 \\
(5,307.54)^{*}\end{array}$ & $\begin{array}{c}-8,448.51 \\
(2,170.44)^{* * *}\end{array}$ \\
\hline Y2004 & $\begin{array}{c}-941.51 \\
(170.31)^{* * *}\end{array}$ & $\begin{array}{c}2,863.48 \\
(618.68)^{* * *}\end{array}$ & $\begin{array}{c}-7,025.19 \\
(5,868.33)^{*}\end{array}$ & $\begin{array}{c}-9,307.29 \\
(2,430.64)^{* * *}\end{array}$ \\
\hline Y2005 & $\begin{array}{c}-1,063.05 \\
(142.95)^{* * *}\end{array}$ & $\begin{array}{c}3,151.72 \\
(591.85)^{* * *}\end{array}$ & $\begin{array}{c}-7,185.56 \\
(6,457.37)^{*}\end{array}$ & $\begin{array}{c}-11,122.28 \\
(2,704.88)^{* * *}\end{array}$ \\
\hline Y2006 & $\begin{array}{c}-1,408.44 \\
(159.54)^{* * *}\end{array}$ & $\begin{array}{c}1,067.74 \\
(814.34)^{*}\end{array}$ & $\begin{array}{l}-10,036.80 \\
(6918.79)^{*}\end{array}$ & $-13,555.85$ \\
\hline Y2007 & $\begin{array}{c}-1,573.69 \\
(141.38)^{* * *}\end{array}$ & $\begin{array}{l}-207.09 \\
(993.87) \\
\end{array}$ & $\begin{array}{c}-13,497.68 \\
(7,256.68)^{* *}\end{array}$ & $\begin{array}{c}-13,306.33 \\
(3,008.65)^{* *}\end{array}$ \\
\hline Adj. R-Square & 0.95 & 0.96 & 0.98 & 0.98 \\
\hline Observations & 1,958 & 2,876 & 5,775 & 52,751 \\
\hline
\end{tabular}

Table 5 shows the estimation results of the hedonic price function as shown in equation (6). The dependent variable is the house price. The model has been estimated nonparametrically using weighted least squares. The standard errors are shown in parentheses below the parameter estimates, and ${ }^{* * *},{ }^{* *}$ and ${ }^{*}$ denote $99 \%, 95 \%$ and $90 \%$ levels of significance, respectively. 


\section{Table 6: Price Reductions}

\begin{tabular}{lcc}
\hline \hline City & Discount: Non-Foreclosed Homes & Discount: Foreclosed Homes \\
\hline Lafayette & -14.81 & $-1,830.62$ \\
Hollywood & -195.23 & $-1,267.62$ \\
Fort Lauderdale & -310.84 & $-3,239.22$ \\
Miami & -234.23 & $-1,928.41$ \\
\hline City & Discount: Small Size & Discount: Large Size \\
\hline Lafayette & $-1,728.42$ & $-1,939.63$ \\
Hollywood & -466.78 & $-4,737.91$ \\
Fort Lauderdale & $-1,336.2$ & $-16,288.48$ \\
Miami & $-1,433.42$ & $-2,623.66$ \\
\hline City & Discount: Low Income & Discount: High Income \\
\hline Lafayette & $-1,960.22$ & $-1,558.45$ \\
Hollywood & $-1,278.38$ & $-1,163.11$ \\
Fort Lauderdale & $-2,179.71$ & $-11,891$ \\
Miami & $-1,714.89$ & $-2,252.70$ \\
\hline Adj. R-Square & see Table 4 & \\
Observations & see Table 4 & \\
\hline \hline
\end{tabular}

Table 6 shows the price reductions due to foreclosure in low and high market segments. Price reductions are based on the estimation results as shown in Table 4.

Table 7: Impact on House Prices by Demographics

\begin{tabular}{lc}
\hline \hline End. Variable: Difference of Residuals & \\
Variable & Estimate \\
\hline Size & -4.51 \\
& $(0.72)^{* * *}$ \\
Income & 0.08 \\
& $(0.05)^{*}$ \\
Family Size & -358.88 \\
& $(1,496.39)$ \\
Mortgage & -9.02 \\
& $(45.47)$ \\
Below Poverty & 102.84 \\
& $(57.46)^{*}$ \\
\hline Adj. R-Square & 0.40 \\
Observations & 118 \\
\hline \hline
\end{tabular}

Table 7 shows the OLS estimation results of magnitude of house price reductions depending on demographics. The standard errors are shown in parentheses below the parameter estimates, and ${ }^{* * *},{ }^{* *}$ and ${ }^{*}$ denote $99 \%, 95 \%$ and $90 \%$ levels of significance, respectively. 
Table 8: Neighborhood Effects

\begin{tabular}{lcc}
\hline \hline Endogenous Variable: P & $\begin{array}{c}\text { Florida } \\
\text { Variable }\end{array}$ & $\begin{array}{c}\text { Indiana } \\
(1)\end{array}$ \\
\hline Size & 12.65 & 5.69 \\
& $(0.07)^{* * *}$ & $(0.18)^{* * *}$ \\
Age & 16.54 & -20.01 \\
& $(1.70)^{* * *}$ & $(6.61)^{* * *}$ \\
DOM & 13.25 & -1.24 \\
& $(0.38)^{* * *}$ & $(0.51)$ \\
Bedr & $4,858.13$ & 27.54 \\
& $(45.36)^{* * *}$ & $(179.66)$ \\
Baths & 77.69 & $1,361.32$ \\
& $(65.45)$ & $(292.69)^{* * *}$ \\
Black & -124.52 & 180.53 \\
& $(1.84)^{* * *}$ & $(246.09)$ \\
White & -27.32 & 3.39 \\
& $(1.58)^{* * *}$ & $(4.97)$ \\
Bachelor & 155.05 & -16.92 \\
& $(2.34)^{* * *}$ & $(19.53)$ \\
Commute & -333.87 & -30.57 \\
& $(3.79)^{* * *}$ & $(19.53)^{*}$ \\
NeighborhoodFC & -216.78 & -531.70 \\
& $(61.95)^{* * *}$ & $(116.29)^{* * *}$ \\
\hline Adj. R-Square & 0.89 & 0.96 \\
Observations & 111,485 & 1,958 \\
\hline \hline
\end{tabular}

Table 8 shows the estimation results of the impact of foreclosure on house prices in the neighborhood, estimated by OLS.

The standard errors are shown in parentheses below the parameter estimates, and ***, ** and * denote $99 \%, 95 \%$ and $90 \%$ levels of significance, respectively. 
Table 9: Estimation Results of the Hedonic Model

\begin{tabular}{|c|c|c|c|c|c|c|}
\hline $\begin{array}{l}\text { Endog. Var: P } \\
\text { Variables }\end{array}$ & $\begin{array}{l}\text { All } \\
(1)\end{array}$ & $\begin{array}{l}\text { IN } \\
(2)\end{array}$ & $\begin{array}{l}\mathrm{FL} \\
(3)\end{array}$ & $\begin{array}{l}\text { All } \\
(4)\end{array}$ & $\begin{array}{l}\text { IN } \\
(5)\end{array}$ & $\begin{array}{l}\text { FL } \\
(6)\end{array}$ \\
\hline Size & $\begin{array}{c}184.96 \\
(0.59)^{* * *}\end{array}$ & $\begin{array}{c}72.39 \\
(1.81)^{* * *}\end{array}$ & $\begin{array}{c}184.15 \\
(0.59)^{* * *}\end{array}$ & $\begin{array}{c}184.95 \\
(0.59)^{* * *}\end{array}$ & $\begin{array}{c}72.08 \\
(1.82)^{* * *}\end{array}$ & $\begin{array}{c}184.14 \\
(0.59)^{* * *}\end{array}$ \\
\hline Age & $\begin{array}{c}407.59 \\
(17.83)^{* * *}\end{array}$ & $\begin{array}{l}-120.54 \\
(49.61)^{* *}\end{array}$ & $\begin{array}{c}469.78 \\
(16.90)^{* * *}\end{array}$ & $\begin{array}{c}407.68 \\
(17.83)^{* * *}\end{array}$ & $\begin{array}{l}-117.78 \\
(49.62)^{* *}\end{array}$ & $\begin{array}{c}469.87 \\
(16.90)^{* * *}\end{array}$ \\
\hline DOM & $\begin{array}{c}219.14 \\
(3.25)^{* * *}\end{array}$ & $\begin{array}{c}-3.46 \\
(10.03)\end{array}$ & $\begin{array}{c}216.89 \\
(3.21)^{* * *}\end{array}$ & $\begin{array}{c}219.15 \\
(3.25)^{* * *}\end{array}$ & $\begin{array}{c}-2.78 \\
(10.03)\end{array}$ & $\begin{array}{c}216.89 \\
(3.21)^{* * *}\end{array}$ \\
\hline Bedr & $\begin{array}{c}45,178 \\
(390.13)^{* * *}\end{array}$ & $\begin{array}{c}1,057.64 \\
(1,752.12)\end{array}$ & $\begin{array}{c}48,624 \\
(384.19)^{* * *}\end{array}$ & $\begin{array}{c}45,179 \\
(390.13)^{* * *}\end{array}$ & $\begin{array}{c}1,223.46 \\
(1,754.18)\end{array}$ & $\begin{array}{c}48,625 \\
(384.19)^{* * *}\end{array}$ \\
\hline Baths & $\begin{array}{c}16,246 \\
(570.96)^{* * *}\end{array}$ & $\begin{array}{c}20,862 \\
(2,107.95)^{* * *}\end{array}$ & $\begin{array}{c}16,291 \\
(555.93)^{* * *}\end{array}$ & $\begin{array}{c}16,242 \\
(570.97)^{* * *}\end{array}$ & $\begin{array}{c}20,915 \\
(2,107.24)^{* * *}\end{array}$ & $\begin{array}{c}16,286 \\
(555.94)^{* * *}\end{array}$ \\
\hline Foreclosure & $\begin{array}{c}-39,405 \\
(3,125.48)^{* * *}\end{array}$ & $\begin{array}{c}-24,887 \\
(6,215.62)^{* * *}\end{array}$ & $\begin{array}{c}-34,929 \\
(3,115.06)^{* * *}\end{array}$ & & & \\
\hline Low Foreclosure & & & & $\begin{array}{c}-41,476 \\
(3.638 .39)^{* * *}\end{array}$ & $\begin{array}{c}-31,904 \\
(7.516 .02)^{* * *}\end{array}$ & $\begin{array}{c}-37,399 \\
(3.623 .69)^{* * *}\end{array}$ \\
\hline High Foreclosure & & & & $\begin{array}{c}-33,902 \\
(6,072.59)^{* * *}\end{array}$ & $\begin{array}{l}-10,091 \\
(10,869)\end{array}$ & $\begin{array}{c}-28,230 \\
(6,063.67)^{* * *}\end{array}$ \\
\hline Black & $\begin{array}{l}-2,349.84 \\
(21.84)^{* * *}\end{array}$ & $\begin{array}{c}3,363.68 \\
(3,196.66)\end{array}$ & $\begin{array}{l}-2,093.98 \\
(19.72)^{* * *}\end{array}$ & $\begin{array}{l}-2,349.59 \\
(21.84)^{* * *}\end{array}$ & $\begin{array}{c}3,510.91 \\
(3,196.45)\end{array}$ & $\begin{array}{l}-2,093.67 \\
(19.72)^{* * *}\end{array}$ \\
\hline White & $\begin{array}{l}-1,173.24 \\
(16.26)^{* * *}\end{array}$ & $\begin{array}{c}42.03 \\
(98.09)\end{array}$ & $\begin{array}{c}-899.35 \\
(13.57)^{* * *}\end{array}$ & $\begin{array}{l}-1,173.16 \\
(16.26)^{* * *}\end{array}$ & $\begin{array}{c}43.66 \\
(98.06)\end{array}$ & $\begin{array}{c}-899.24 \\
(13.57)^{* * *}\end{array}$ \\
\hline Schoolscore & & $\begin{array}{c}7,421.68 \\
(1,660.96)^{* * *}\end{array}$ & & & $\begin{array}{c}7,272.79 \\
(1,662.64)^{* * *}\end{array}$ & \\
\hline Bachelor & $\begin{array}{c}2,123.46 \\
(19.56)^{* * *}\end{array}$ & $\begin{array}{c}-723.17 \\
(268.26)^{* * *}\end{array}$ & $\begin{array}{c}2,184.29 \\
(19.27)^{* * *}\end{array}$ & $\begin{array}{c}2,123.73 \\
(19.56)^{* * *}\end{array}$ & $\begin{array}{c}-717.98 \\
(268.15)^{* * *}\end{array}$ & $\begin{array}{c}2,184.61 \\
(19.27)^{* * *}\end{array}$ \\
\hline Commute & $\begin{array}{l}-4,442.49 \\
(45.06)^{* * *}\end{array}$ & $\begin{array}{c}-507.16 \\
(218.66)^{* *}\end{array}$ & $\begin{array}{l}-4,306.27 \\
(38.89)^{* * *}\end{array}$ & $\begin{array}{l}-4,442.05 \\
(45.06)^{* * *}\end{array}$ & $\begin{array}{c}-520.46 \\
(218.71)^{* *}\end{array}$ & $\begin{array}{l}-4,305.69 \\
(38.90)^{* * *}\end{array}$ \\
\hline Florida & $\begin{array}{c}42,130 \\
(2,056.76)^{* * *}\end{array}$ & & & $\begin{array}{c}42,131 \\
(2,056.76)^{* * *}\end{array}$ & & \\
\hline Y2001 & $\begin{array}{c}-31,925 \\
(1,382.63)^{* * *}\end{array}$ & $\begin{array}{c}9,864.42 \\
(3,965.10)^{* *}\end{array}$ & $\begin{array}{c}-26,778 \\
(1,351.72)^{* * *}\end{array}$ & $\begin{array}{c}-31,923 \\
(1,382.63)^{* * *}\end{array}$ & $\begin{array}{c}9,874.99 \\
(3,963.32)^{* *}\end{array}$ & $\begin{array}{c}-26,776 \\
(1,351.72)^{* * *}\end{array}$ \\
\hline Y2002 & $\begin{array}{c}-15,312 \\
(1,197.72)^{* * *}\end{array}$ & $\begin{array}{c}-836.62 \\
(4,056.96)\end{array}$ & $\begin{array}{c}-9,304.98 \\
(1,160.91)^{* * *}\end{array}$ & $\begin{array}{c}-15,317 \\
(1,197.73)^{* * *}\end{array}$ & $\begin{array}{c}-821.03 \\
(4,055.14)\end{array}$ & $\begin{array}{c}-9,310.71 \\
(1,160.92)^{* * *}\end{array}$ \\
\hline Y2003 & $\begin{array}{c}1,718.59 \\
(1,117.07)\end{array}$ & $\begin{array}{l}-1,657.72 \\
(3,992.22)\end{array}$ & $\begin{array}{c}9,310.99 \\
(1,072.86)^{* * *}\end{array}$ & $\begin{array}{c}1,713.81 \\
(1,117.08)\end{array}$ & $\begin{array}{l}-1,653.62 \\
(3,990.42)\end{array}$ & $\begin{array}{c}9,305.04 \\
(1,072.87)^{* * *}\end{array}$ \\
\hline Y2004 & $\begin{array}{c}6,226.25 \\
(1,118.22)^{* * *}\end{array}$ & $\begin{array}{c}-11,208 \\
(3,331.75)^{* * *}\end{array}$ & $\begin{array}{c}14,946 \\
(1,078.14)^{* * *}\end{array}$ & $\begin{array}{c}6,217.76 \\
(1,118.24)^{* * *}\end{array}$ & $\begin{array}{c}-11,253 \\
(3,330.35)^{* * *}\end{array}$ & $\begin{array}{c}14,936 \\
(1,078.16)^{* * *}\end{array}$ \\
\hline Y2005 & $\begin{array}{c}7,392.68 \\
(1,137.42)^{* * *}\end{array}$ & $\begin{array}{c}-13,306 \\
(3,345.57)^{* * *}\end{array}$ & $\begin{array}{c}16,072 \\
(1,098.05)^{* * *}\end{array}$ & $\begin{array}{c}7,386.19 \\
(1,137.43)^{* * *}\end{array}$ & $\begin{array}{c}-13,182 \\
(3,344.89)^{* * *}\end{array}$ & $\begin{array}{c}16,064 \\
(1,098.06)^{* * *}\end{array}$ \\
\hline Y2006 & $\begin{array}{c}-32,599 \\
(1,194.29)^{* * *}\end{array}$ & $\begin{array}{c}-18,792 \\
(3,350.88)^{\text {*** }}\end{array}$ & $\begin{array}{c}-23,274 \\
(1,158.86)^{* * *}\end{array}$ & $\begin{array}{c}-32,606 \\
(1,194.30)^{* * *}\end{array}$ & $\begin{array}{c}-18,748 \\
(3,349.47)^{* * *}\end{array}$ & $\begin{array}{c}-23,282 \\
(1,158.87)^{* * *}\end{array}$ \\
\hline Y2007 & $\begin{array}{c}-58,976 \\
(1,284.68)^{* * *}\end{array}$ & $\begin{array}{c}-22,065 \\
(3,451.58)^{* * *}\end{array}$ & $\begin{array}{c}-49,806 \\
(1,256.94)^{* * *}\end{array}$ & $\begin{array}{c}-58,979 \\
(1,284.67)^{* * *}\end{array}$ & $\begin{array}{c}-21,999 \\
(3,450.25)^{* * *}\end{array}$ & $\begin{array}{c}-49,809 \\
(1,256.93)^{* * *}\end{array}$ \\
\hline Adj. R-Square & 0.90 & 0.96 & 0.90 & 0.90 & 0.96 & 0.90 \\
\hline Observations & 309,030 & 1,958 & 307,072 & 309,030 & 1,958 & 307,072 \\
\hline
\end{tabular}

Table 9 shows the estimation results of the hedonic model, as shown in equation (11). The dependent variable is the house

price. The error is assumed to be normally distributed and the model has been estimated using OLS. The standard errors

are shown in parentheses below the parameter estimates, and ${ }^{* * *},{ }^{* *}$ and ${ }^{*}$ denote $99 \%, 95 \%$ and $90 \%$ levels of significance, 
Table 10: Estimation Results of the Hedonic Model, City level

\begin{tabular}{|c|c|c|c|c|c|c|}
\hline $\begin{array}{l}\text { Endog. Var: Price } \\
\text { Variables }\end{array}$ & $\begin{array}{l}\text { Hollyw. } \\
\text { (1) }\end{array}$ & $\begin{array}{l}\text { Ft. Laud. } \\
\text { (2) }\end{array}$ & $\begin{array}{l}\text { Miami } \\
(3)\end{array}$ & $\begin{array}{l}\text { Hollyw. } \\
\text { (4) }\end{array}$ & $\begin{array}{l}\text { Ft. Laud. } \\
\text { (5) }\end{array}$ & $\begin{array}{l}\text { Miami } \\
(6)\end{array}$ \\
\hline Size & 181.03 & 277.70 & 90.56 & 181.16 & 277.99 & 90.50 \\
\hline & $(3.77)^{* * *}$ & $(5.92)^{* * *}$ & $(0.92)^{* * *}$ & $(3.77)^{* * *}$ & $(5.92)^{* * *}$ & $(0.92)^{* * *}$ \\
\hline Age & 34.12 & $-1,155.28$ & -324.05 & 37.01 & $-1,159.36$ & -323.50 \\
\hline & (107.24) & $(167.92)^{* * *}$ & $(23.14)^{* * *}$ & $(107.29)$ & $(167.91)^{* * *}$ & $(23.14)^{* * *}$ \\
\hline DOM & 69.70 & 117.98 & 88.20 & 69.43 & 118.46 & 88.18 \\
\hline & $(22.79)^{* * *}$ & $(26.74)^{* * *}$ & $(5.28)^{* * *}$ & $(22.79)^{* * *}$ & $(26.74)^{* * *}$ & $(5.28)^{* * *}$ \\
\hline Bedr & 44,574 & 73,859 & 131,803 & 44,512 & 73,797 & 131,789 \\
\hline & $(2,686.87)^{* * *}$ & $(3,141.34)^{* * *}$ & $(776.23)^{* * *}$ & $(2,687.71)^{* * *}$ & $(3,141.12)^{* * *}$ & $(776.19)^{* * *}$ \\
\hline Baths & $8,406.67$ & $-20,129$ & 13,814 & $8,446.07$ & $-20,148$ & 13,789 \\
\hline Foreclosure & $\begin{array}{c}(2,985.37)^{* * *} \\
-20,020 \\
(13,291)\end{array}$ & $\begin{array}{c}(4,751.85)^{* * *} \\
-49,448 \\
(20,316)^{* * *}\end{array}$ & $\begin{array}{c}(835.57)^{* * *} \\
-20,665 \\
(4,072.79)^{* * *}\end{array}$ & $(2,985.72)^{* * *}$ & $(4,751.19)^{* * *}$ & $(835.56)^{* * *}$ \\
\hline Low Foreclosure & & & & $\begin{array}{l}-10,982 \\
(16,360)\end{array}$ & $\begin{array}{l}-30,219 \\
(23,514)\end{array}$ & $\begin{array}{c}-27,150 \\
(4,679.06)^{* * *}\end{array}$ \\
\hline High Foreclosure & & & & $\begin{array}{c}-37,253 \\
(22,527)^{*}\end{array}$ & $\begin{array}{c}-104,954 \\
(39,769)^{* * *}\end{array}$ & $\begin{array}{c}-763.98 \\
(8,159.65)\end{array}$ \\
\hline Black & $\begin{array}{l}-120.88 \\
(254.79)\end{array}$ & $\begin{array}{c}-545.17 \\
(286.14)^{* *}\end{array}$ & $\begin{array}{c}793.79 \\
(42.45)^{* * *}\end{array}$ & $\begin{array}{l}-113.78 \\
(254.91)\end{array}$ & $\begin{array}{c}-562.54 \\
(286.30)^{* *}\end{array}$ & $\begin{array}{c}795.14 \\
(42.45)^{* * *}\end{array}$ \\
\hline White & $\begin{array}{c}562.21 \\
(229.12)^{* *}\end{array}$ & $\begin{array}{l}-2,900.13 \\
(330.11)^{* * *}\end{array}$ & $\begin{array}{c}3,441.27 \\
(65.18)^{* * *}\end{array}$ & $\begin{array}{c}565.79 \\
(229.16)^{* *}\end{array}$ & $\begin{array}{c}-2,921.22 \\
(330.32)^{* * *}\end{array}$ & $\begin{array}{c}3,441.84 \\
(65.17)^{* * *}\end{array}$ \\
\hline Bachelor & $\begin{array}{l}-1,246.47 \\
(195.16)^{* * *}\end{array}$ & $\begin{array}{c}9,632.20 \\
(362.96)^{* * *}\end{array}$ & $\begin{array}{c}-244.48 \\
(32.01)^{* * *}\end{array}$ & $\begin{array}{l}-1,249.64 \\
(195.19)^{* * *}\end{array}$ & $\begin{array}{c}9,643.77 \\
(362.98)^{* * *}\end{array}$ & $\begin{array}{c}-243.75 \\
(32.01)^{* * *}\end{array}$ \\
\hline Commute & $\begin{array}{l}-5,112.55 \\
(528.24)^{* * *}\end{array}$ & $\begin{array}{l}-2,800.14 \\
(663.25)^{* * *}\end{array}$ & $\begin{array}{l}-4,657.02 \\
(81.69)^{* * *}\end{array}$ & $\begin{array}{l}-5,126.09 \\
(528.44)^{* * *}\end{array}$ & $\begin{array}{l}-2,787.21 \\
(663.21)^{* * *}\end{array}$ & $\begin{array}{l}-4,654.04 \\
(81.69)^{* * *}\end{array}$ \\
\hline Y2001 & $\begin{array}{l}-23,625 \\
(20,281)\end{array}$ & $\begin{array}{l}-239,268 \\
(25,915)^{* * *}\end{array}$ & & $\begin{array}{l}-23,942 \\
(20,284)\end{array}$ & $\begin{array}{l}-239,555 \\
(25,912)^{* * *}\end{array}$ & \\
\hline Y2002 & $\begin{array}{c}26,486 \\
(16,977)\end{array}$ & $\begin{array}{l}-105,215 \\
(19,127)^{* * *}\end{array}$ & $\begin{array}{c}-171,098 \\
(5,215.12)^{* * *}\end{array}$ & $\begin{array}{c}26,351 \\
(16,978)\end{array}$ & $\begin{array}{l}-104,431 \\
(19,130)^{* * *}\end{array}$ & $\begin{array}{c}-171,157 \\
(5,214.82)^{* * *}\end{array}$ \\
\hline Y2003 & $\begin{array}{c}39,244 \\
(16,860)^{* *}\end{array}$ & $\begin{array}{c}-99,723 \\
(19,057)^{* * *}\end{array}$ & $\begin{array}{c}-158,257 \\
(4,844.49)^{* * *}\end{array}$ & $\begin{array}{c}39,173 \\
(16,860)^{* *}\end{array}$ & $\begin{array}{c}-98,633 \\
(19,066)^{* * *}\end{array}$ & $\begin{array}{c}-158,245 \\
(4,844.17)^{* * *}\end{array}$ \\
\hline Y2004 & $\begin{array}{c}42,638 \\
(16,860)^{* * *}\end{array}$ & $\begin{array}{l}-108,299 \\
(19,225)^{* * *}\end{array}$ & $\begin{array}{c}-171,932 \\
(4,875.13)^{* * *}\end{array}$ & $\begin{array}{c}42,592 \\
(16,861)^{* * *}\end{array}$ & $\begin{array}{l}-107,330 \\
(19,068)^{* * *}\end{array}$ & $\begin{array}{c}-171,940 \\
(4,874.81)^{* * *}\end{array}$ \\
\hline Y2005 & $\begin{array}{c}47,694 \\
(16,976)^{* * *}\end{array}$ & $\begin{array}{l}-116,151 \\
(19,225)^{* * *}\end{array}$ & $\begin{array}{c}47,650 \\
(4,904.24)^{* * *}\end{array}$ & $\begin{array}{l}-196,464 \\
(16,977)^{* * *}\end{array}$ & $\begin{array}{c}-115,100 \\
(19,234)^{* * *}\end{array}$ & $\begin{array}{c}-196,457 \\
(4,903.92)^{* * *}\end{array}$ \\
\hline Y2006 & $\begin{array}{c}18,605 \\
(17,133)\end{array}$ & $\begin{array}{c}-153,375 \\
(19,633)^{* * *}\end{array}$ & $\begin{array}{c}-229,907 \\
(4,940.77)^{* * *}\end{array}$ & $\begin{array}{c}18,602 \\
(17,133)\end{array}$ & $\begin{array}{l}-152,522 \\
(19,637)^{* * *}\end{array}$ & $\begin{array}{c}-229,909 \\
(4,940.45)^{* * *}\end{array}$ \\
\hline Y2007 & $\begin{array}{c}75.11 \\
(17,440)\end{array}$ & $\begin{array}{c}-201,335 \\
(20,068)^{* * *}\end{array}$ & $\begin{array}{c}-227,307 \\
(5,208.32)^{* * *}\end{array}$ & $\begin{array}{c}10,198 \\
(17,441)\end{array}$ & $\begin{array}{c}-200,409 \\
(20,073)^{* * *}\end{array}$ & $\begin{array}{c}-227,283 \\
(5,027.99)^{* * *}\end{array}$ \\
\hline Adj. R-Square & 0.96 & 0.90 & 0.95 & 0.96 & 0.90 & 0.95 \\
\hline Observations & 2,876 & 5,775 & 52,751 & 2,876 & 5,775 & 52,751 \\
\hline
\end{tabular}

Table 10 shows the estimation results of the hedonic model, as shown in equation (11). The dependent variable is the house

price. The error is assumed to be normally distributed and the model has been estimated using OLS. The standard errors are shown in parentheses below the parameter estimates, and ${ }^{* * *},{ }^{* *}$ and ${ }^{*}$ denote $99 \%, 95 \%$ and $90 \%$ levels of significance, respectively. 


\section{B Appendix: Figures}

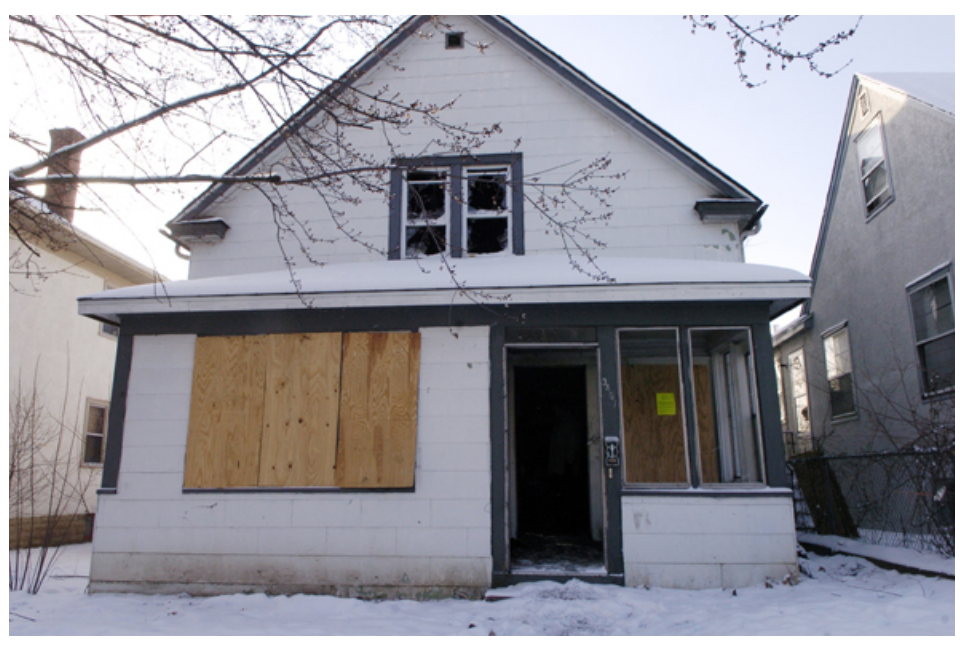

Figure 1: Foreclosed House (Exterior)

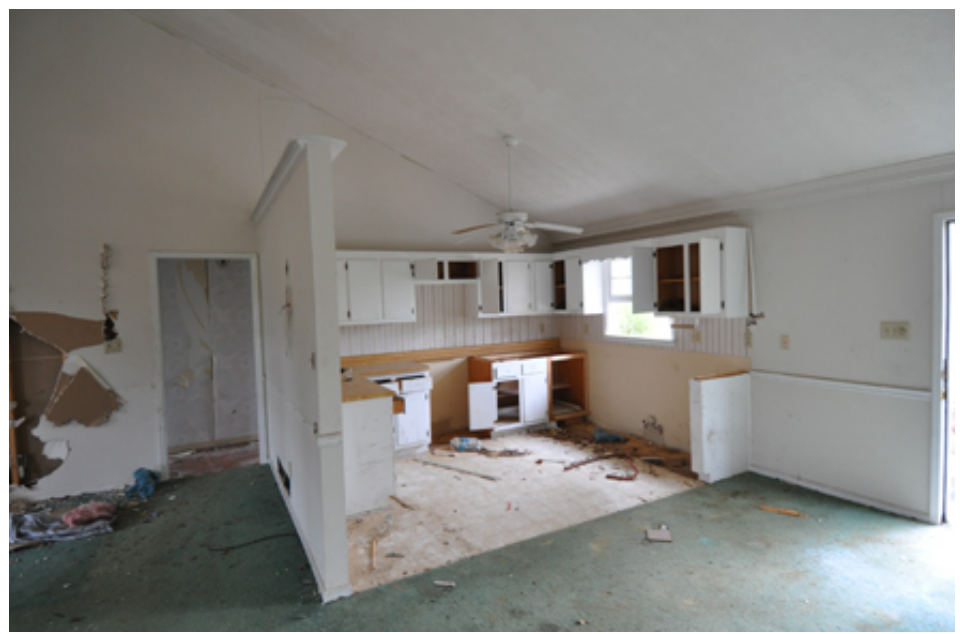

Figure 2: Foreclosed House (Interior1)

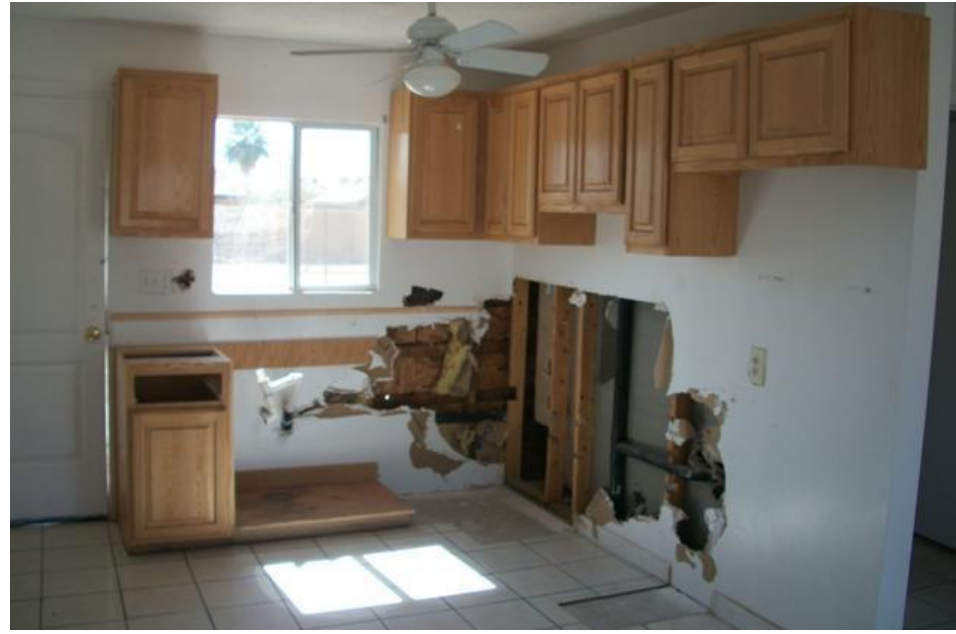

Figure 3: Foreclosed House (Interior2) 


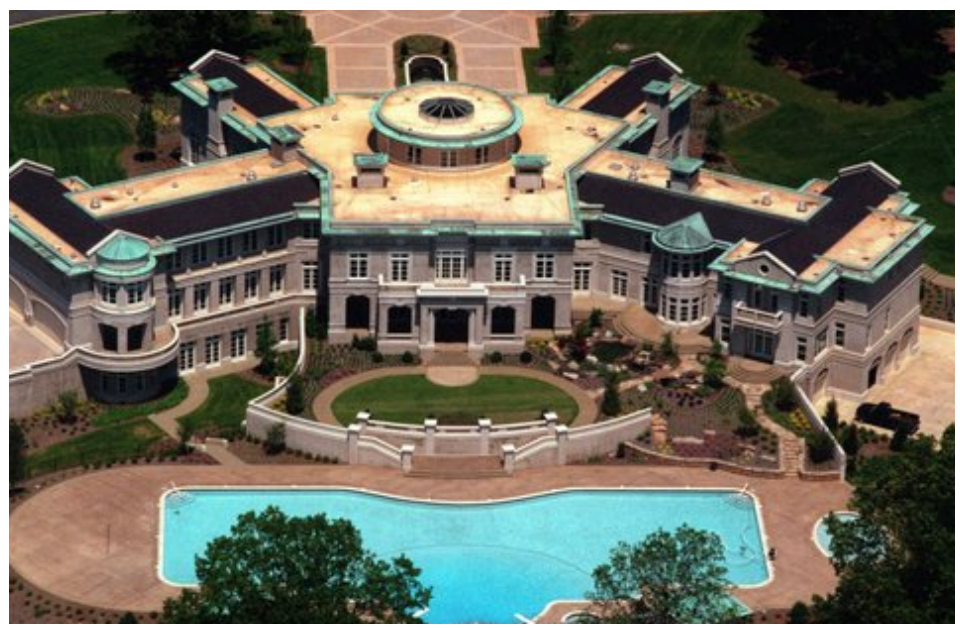

Figure 4: Foreclosed Villa by Holyfield

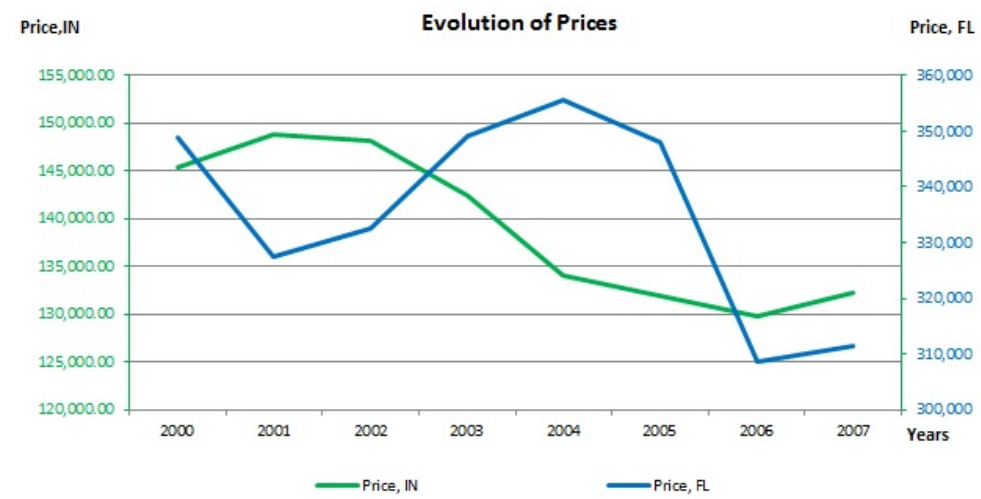

Figure 5: Evolution of Prices

Source: RealtyTrac.com and Multiple Listing Service.

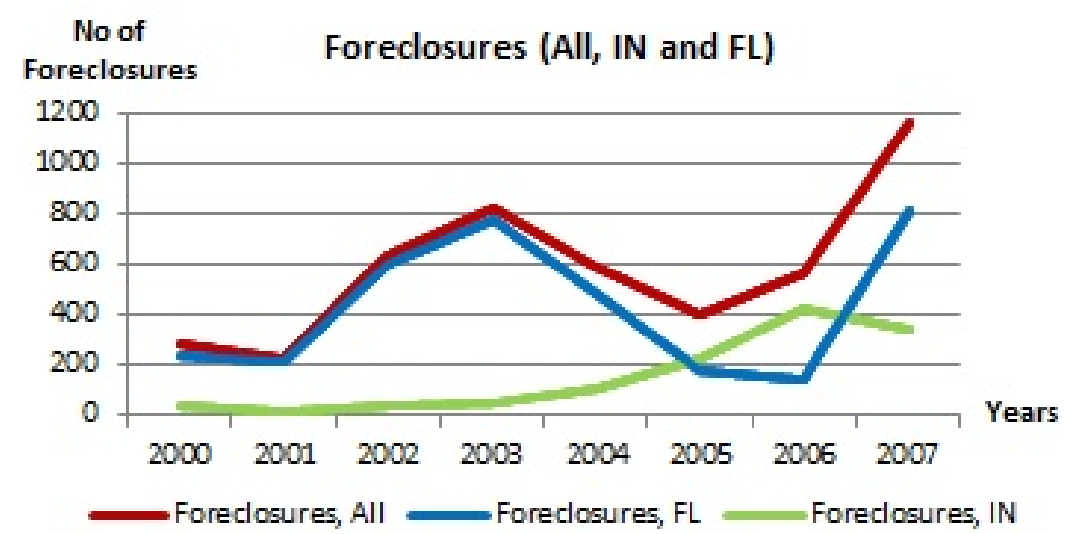

Figure 6: Evolution of Foreclosures

Source: RealtyTrac.com and Multiple Listing Service. 


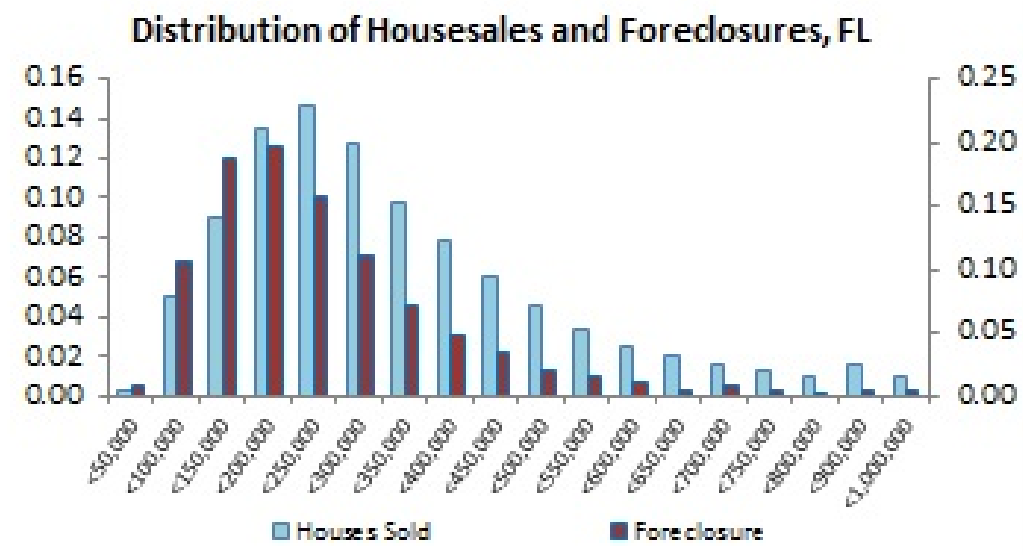

Figure 7: Distributions of Homesales and Foreclosure along Price, FL Source: RealtyTrac.com and Multiple Listing Service.

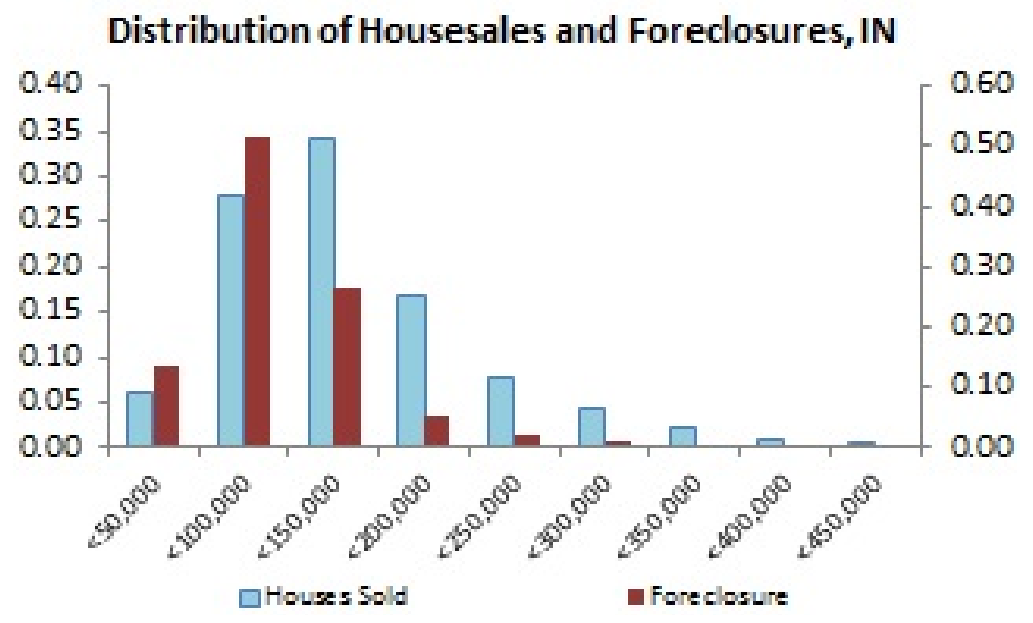

Figure 8: Distributions of Homesales and Foreclosure along Price, IN Source: RealtyTrac.com and Multiple Listing Service. 
Residuals along Housesize: Hollywood, noFC
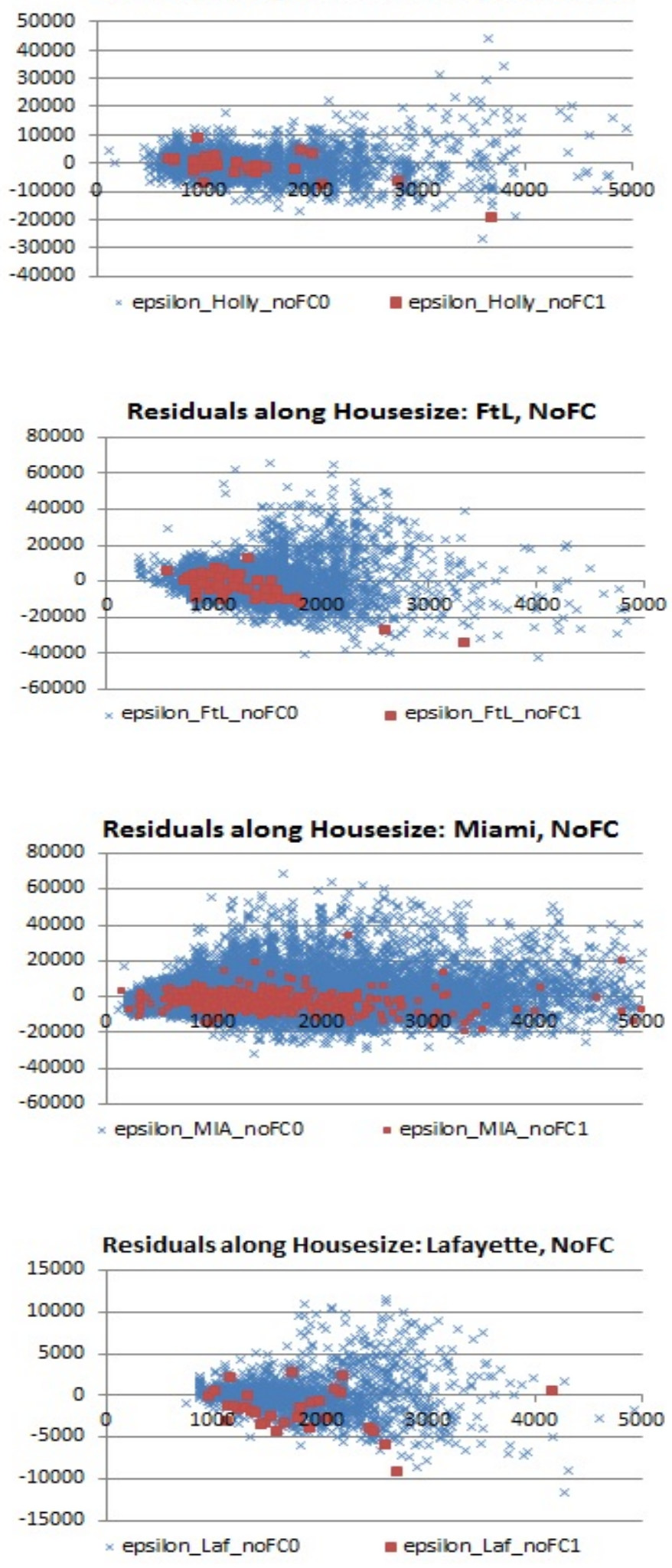

Figure 9: Distribution of Residuals along Housesize: No FC Dummy Source: RealtyTrac.com and Multiple Listing Service. 

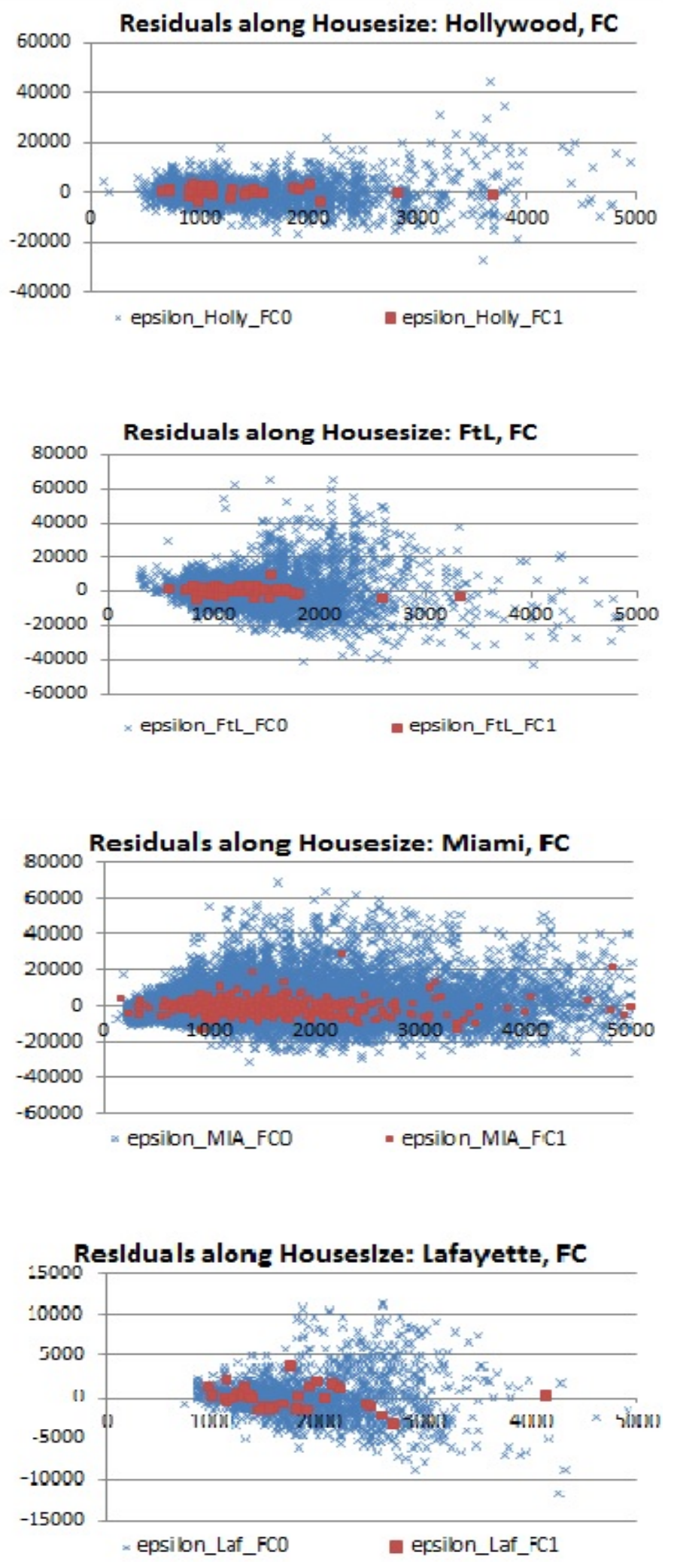

Figure 10: Distribution of Residuals along Housesize: FC Dummy Source: RealtyTrac.com and Multiple Listing Service. 